Article

\title{
Energy System Transitions in the Eastern Coastal Metropolitan Regions of China-The Role of Regional Policy Plans
}

\author{
Mengzhu Xiao*, Sonja Simon ${ }^{(1)}$ and Thomas Pregger ${ }^{(0)}$ \\ Department of Energy Systems Analysis, Institute of Engineering Thermodynamics, German Aerospace \\ Center (DLR), Pfaffenwaldring 38-40, 70569 Stuttgart, Germany; Sonja.Simon@dlr.de (S.S.); \\ Thomas.Pregger@dlr.de (T.P.) \\ * Correspondence: Mengzhu.Xiao@dlr.de; Tel.: +49-711-6862-432
}

Received: 2 July 2018; Accepted: 24 January 2019; Published: 26 January 2019

check for updates

\begin{abstract}
With an expected accelerated urbanization process until 2050, China is facing big challenges of mitigating $\mathrm{CO}_{2}$ emissions, especially in the eastern coastal metropolitan regions. Since cities are the hubs for innovation regarding new technologies and infrastructures, investments and governance, they are playing an important role in decision-making and implementation processes on the way to a decarbonized economy and society. The national and provincial administrations in China have already started to address the issue of energy system transition toward a low-carbon pathway, but long-term integrated transition plans are not yet available on a regional level. In our paper, we therefore consider the main challenges of the energy system transition, such as efficiency improvement, coal reduction, decarbonization of transport, and multisector electrification with regional integration, focusing on two eastern coastal metropolitan regions of China. A systematic review of current near-term policies reveals how far these challenges have already been addressed on different administrative levels and which gaps may exist from an external perspective. Based on the current decision- and policy-making processes among national, regional, provincial and municipal levels, policy implications are identified with regard to an effective energy system transition in eastern China.
\end{abstract}

Keywords: energy system transition; decarbonization; metropolitan region; eastern China; regional policy

\section{Introduction and Background}

According to the Intergovernmental Panel on Climate Change (IPCC), greenhouse gas (GHG) emissions need to decrease by $70-95 \%$ until 2050 for a significant chance to keep the temperature increase well below $2{ }^{\circ} \mathrm{C}$. With almost $80 \%$ of all $\mathrm{CO}_{2}$ emissions, the energy sector must be the focus of mitigation [1]. Additionally, it becomes increasingly obvious that China will play a role, if not the major role, in transforming the energy system: "When China changes, everything changes" ([2], p. 25). Ratifying the Paris Treaty in 2016, China committed itself to the global climate target. This commitment poses huge challenges for the energy system, with the Chinese president calling for no less than an "energy revolution" [2]. The main imminent challenges specific to the country have already been identified. By and large these are: (1) limiting the growth of energy demand, (2) phasing out fossil fuels, especially coal, and (3) integrating large shares of renewable energy (RE) sources into the system $[2,3]$.

Cities account for $70 \%$ of gross domestic product (GDP), over $60 \%$ of global energy consumption, and $70 \%$ of greenhouse gas (GHG) emissions [4]. Important global agendas addressing sustainable urbanization are the Sustainable Development Goals (SDGs) and the New Urban Agenda [5]. Both have 
a broad range of ambitious development goals and visions regarding, e.g., safety, sustainability, and resilience. Also, the Paris Agreement, which is much more focused on climate change, implies ambitious development goals for cities and urban agglomerations. Improving energy efficiency and reducing $\mathrm{CO}_{2}$ emissions from the energy supply have become major tasks for sustainable urban development [6,7]. However, especially in cities, a transition of the energy system is difficult to implement as the demand is high and the RE potentials are low. Thus, RE expansion requires integrated strategies for the joint development of cities and their hinterlands.

Various scientific studies already exist on necessary or achievable energy transition processes in China. Several long-term scenarios have explored target-oriented pathways toward a low-carbon-energy future on the national level $[8,9]$. China's energy transition toward the $2{ }^{\circ} \mathrm{C}$ goal until 2100 were examined in [10] in a bottom-up model with non-fossil energy accounting for $50-70 \%$ and $85 \%$ of primary energy consumption in 2050 and 2100, respectively. In a high renewable penetration scenario analysis, the percentage of RE in the primary energy supply would reach $62 \%$ by 2050 according to [3]. In addition, decarbonization scenarios for China can be found in global scenario studies such as World Energy Outlook 2017 [2] and Energy [R]evolution: A Sustainable World Energy Outlook 2015 [11]. However, current policies in China still seem to have no clear vision for the role of RE sources in the long-term future. The new five-year plans on different administrative levels released recently define short-term targets mainly for the energy system in 2020 [12]. These kinds of near-term policies have a strong impact on market development and infrastructure and thus have important implications for further long-term transformation pathways (see, e.g., [13,14]). Just recently, China Renewable Energy Outlook 2017 (CREO) [3] identified a gap between the currently available policy on the national level and the necessary development to comply with the Paris Agreement.

Additionally, [3] picked the specific example of the Beijing-Tianjin-Hebei (BTH) region to identify the significance of regional integrated policy development for successful energy system transition. In general, the regional dimension plays an important role in sustainable energy system transitions, demanding integrated strategies of subnational governments (see, e.g., [15]). This obviously also holds true for a large country such as China, where energy transition policies need to be embedded in regional development plans [16] to coordinate cities and their hinterlands in terms of energy supply and demand and implementation of national policies [4].

The cities in the eastern coastal metropolitan regions of China are focal points of energy demand in terms of electricity, heat, cold, and mobility due to high population densities and economic activities. In addition, with the different roles cities are playing in industry, service, commerce, education, cultural environment, and tourism, they can particularly promote changes in energy-consumption structures. The provincial-level cities Beijing, Tianjin, and Shanghai are each home to a population of more than 10 million, thus they are megacities according to the definition of the UN [17]. They are characterized by high economic growth rates and large industrial economic structures, but also considerable service-oriented economic activities. However, they all have a limited hinterland and RE resources. Due to the fast urbanization and industrialization processes, serious air pollution has developed and urbanized areas have become major contributors to global GHG emissions [18]. However, a transition toward low-carbon-emission pathways poses novel challenges beyond traditional planning and urban development polices $[19,20]$. Current fossil fuel-dominated energy supply systems and industries are the major sources of $\mathrm{CO}_{2}, \mathrm{PM}_{2.5}$, and $\mathrm{SO}_{2}$ emissions, while transport also significantly contributes to $\mathrm{NO}_{\mathrm{x}}$ emissions. In particular, coal reduction and transport decarbonization are key strategies to improving air quality, which is therefore an important driver of the energy system transition, especially for the eastern coastal metropolitan regions of China.

The provincial administrations in China have already started to address the topic of energy system transition. A variety of local policy plans have been released to tackle RE expansion by provincial authorities. However, long-term integrated energy plans are not yet available, nor is it clear whether the most pressing challenges of the energy transition are sufficiently and simultaneously addressed in the existing policy plans within the regions. In our paper, we therefore analyze whether existing energy 
policy plans at different administrative levels in China are suitable for addressing the challenges of a long-term energy system transition and discuss the possible technical and administrative barriers for the successful implementation of regional policies.

\section{Methodology and Workflow}

The analysis is based on an overview of major challenges of energy system transition in China on the regional level and the identification of key transition aspects and required actions. In order to analyze the regional policies, we selected regions in China that are specifically affected by these challenges. We consider two metropolitan regions in eastern China, the Beijing-Tianjin-Hebei (BTH) region and the Yangtze River Delta (YRD) region, each of which plays a central role in the Chinese energy system in terms of economic growth and energy consumption, while they have significant differences in the energy system layout. A detailed characterization of the energy systems of the two metropolitan regions is provided in Section 3, including a well-founded picture of the current situation, followed by a discussion of specific challenges, transition aspects, and fields for policy interventions for the energy system transition in Section 4. In Section 5 we provide a systematic review of current available policies related to energy transition targets at different administrative levels. The analysis finally focuses on how these policy plans comply with the main challenges. We specifically identify where regional policies currently fail to pave the way for a target-oriented energy system transition at the beginning of Section 6 and discuss possible implications for regional integration to solve the challenges from a long-term perspective. Figure 1 provides an overview of our approach for this analysis.

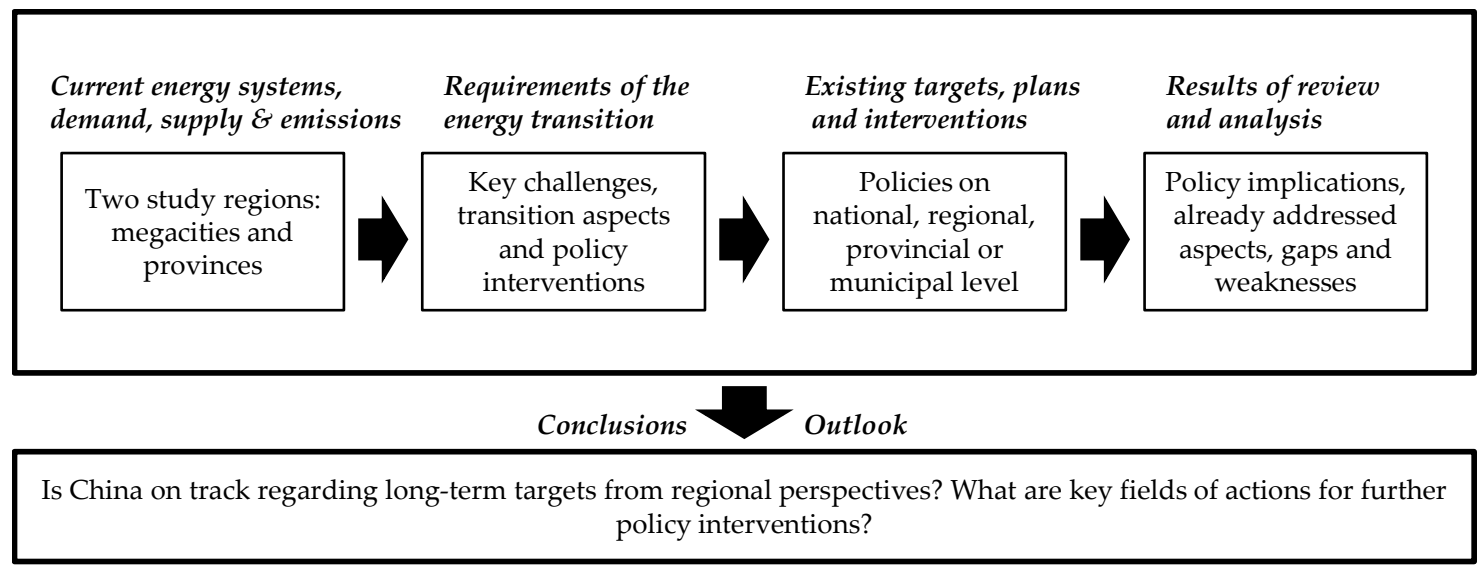

Figure 1. Overview of the methodological approach for the policy analysis.

\section{Study Regions}

Due to the distribution of natural resources and various geographic conditions, population density and economic activity are unbalanced in China, especially between eastern and western parts of the country. This is also reflected in the spatial structure of energy demand and supply. The two study regions are located in eastern China in different climate zones, implying different heating and cooling demands. Regional and national energy balance tables from China Energy Statistical Yearbook 2016 [21] can be used to compare current energy supply and consumption structures. The provided conversion factors are used for universal energy unit calculation from original physical quantities. Data on population, urbanization rate, and added value by sector in 2015 are taken from the China Statistical Yearbook 2016 [21].

The BTH region consists of two provincial-level cities, Beijing and Tianjin, and the province of Hebei. It is located in a humid continental climate zone, resulting in significant heating demand during the winter season, which is often covered by district heat. The YRD region, with one provincial-level city, Shanghai, and two provinces, Jiangsu and Zhejiang, is located in a subtropical climate zone 
characterized by hot summers and temperate winters with more cooling demand in the summer season. Currently, no widespread district heating system is implemented in this region. The energy demand is quite high in both study regions, accounting for $12 \%$ and $15 \%$ of national energy demand, respectively, in 2015 [21]. With an agglomeration of population and economy as well as continuous urbanization, the energy demand is expected to grow further if no effective efficiency control measures are taken. Main characteristics of both regions are summarized in Table 1.

Table 1. Main characteristics of the two study regions in 2015 with comparison to national average. BTH: Beijing-Tianjin-Hebei; YRD: Yangtze River Delta; GDP: gross domestic product; PPP: purchasing power parity; PJ: Petajoule; MJ: Megajoule; TWh: Terawatt-hour.

\begin{tabular}{cccc}
\hline Aspect & Unit & BTH Metropolitan Region & YRD Metropolitan Region \\
\hline Administration & $\mathrm{Km}^{2}$ & Beijing, Tianjin, Hebei Province & Shanghai, Jiangsu, Zhejiang Province \\
\hline Area & & $\begin{array}{c}\text { Warm-temperature zone } \\
\text { includes cold temperature in } \\
\text { northern mountainous area }\end{array}$ & $\begin{array}{c}\text { Transition area between warm-temperature } \\
\text { and subtropical zones }\end{array}$ \\
\hline Temperature zone & million & 111 & 159 \\
\hline Population & $\%$ & 8 & 12 \\
\hline Population density & $\mathrm{cap} / \mathrm{m}^{2}$ & 0.5 & 0.8 \\
\hline $\begin{array}{c}\text { Multiple of national } \\
\text { average }\left(0.14 \text { cap } \mathrm{m}^{2}\right)\end{array}$ & - & 4 & 5 \\
\hline GDP (PPP) & $\$$ trillion & 2 & 19 \\
\hline$\%$ of national & $\%$ & 10 & 25,334 \\
\hline GDP/cap & $\$$ & 18,109 & 13,574 \\
\hline Energy demand & $\mathrm{PJ} / \mathrm{yr}$ & 11,422 & 15 \\
\hline$\%$ of national & $\%$ & 12 & 3.4 \\
\hline Energy demand per GDP & $\mathrm{MJ} / \$$ & 5.7 & 18 \\
\hline Electricity demand & $\mathrm{TWh} / \mathrm{yr}$ & 467 & \\
\hline$\%$ of national & $\%$ & 8 & \\
\hline
\end{tabular}

In 2015 , the population of the two study regions accounted for $8 \%$ and $12 \%$ of the national population, respectively [21]. The population densities in BTH and YRD are four to five times higher than the national average. The GDP per capita is also significantly higher in the two regions than the national average of 53,000 RMB per capita. In 2015, the GDP of the two study regions accounted for $29 \%$ of the national GDP [21]. In the same year, the energy demand accounted for $27 \%$ of the national energy demand, according to [22]. Also, the specific energy consumption per GDP in BTH is significantly higher than the national average of $1.3 \mathrm{MJ} / \mathrm{RMB}$. The YRD region specifically accounts for a disproportionately high share of national GDP and electricity demand.

The current energy supply and consumption structures for the study regions and China are shown in the Appendix A: Figures A1-A3. Figure A4 shows the main emissions of $\mathrm{CO}_{2}, \mathrm{SO}_{2}, \mathrm{PM}_{2.5}$, and $\mathrm{NO}_{\mathbf{x}}$ in 2010 by sector in the two study regions as well as in China. The following sections highlight specific characteristics of the two study regions regarding energy production and use.

\subsection{Characteristics of Energy Supply}

Except Beijing, all considered municipalities and provinces currently have coal-dominated heat and power supply systems, especially in Hebei Province, with shares higher than the national average. In the two municipalities of Tianjin and Shanghai, natural gas is used for around $10 \%$ of public power and heat supply, and in Beijing the share of natural gas is $54 \%$ for public heating plants and $82 \%$ for public power generation. Except in Beijing, with oil-dominated industrial energy consumption, coal is also the main final energy use in industry, but with regional differences: Beijing, Shanghai, and Zhejiang are well below the national average, while Hebei's consumption is much higher, with a 
coal share of $80 \%$. The BTH region has a higher heat demand in residential and service sectors than the YRD region due to different temperature zones. District heating systems have a significant share in urban areas of BTH supplemented by a mixture of other technologies, mainly oil heaters. In rural areas, the use of coal in small boilers is still dominant in the residential sector. The shares of coal use are higher than the national average and reach $65 \%$ in Beijing, $64 \%$ in Hebei, and $48 \%$ in Tianjin. Compared to BTH, the final energy consumption of the residential sector in YRD is composed of different shares of electricity, oil, and gas.

Energy consumption for transportation is clearly dominated by oil products, similar to other countries, although electric vehicles have achieved a mass market in China. Except for Shanghai and Zhejiang, the share of oil products in urban areas is higher than their rural counterparts due to higher ownership of private cars. The shares of electricity and natural gas are still small and differ among regions. However, in Hebei and Tianjin, electricity reaches a share of $12 \%$ of final energy due to the high importance of public transportation.

The electrification rate is also an important characteristic of energy systems. Generally speaking, the YRD region has higher shares of electricity in end-use sectors than China on average due to the cooling demand in summer and power demand in industry. Still, coal consumption is dominant in industry and electricity is mainly used for electrical appliances and mechanical energy. Electricity reaches only small shares in BTH, but, as already mentioned, with higher shares in Tianjin and Hebei compared to the Chinese average. However, the current statistics reveal still huge potential for further electrification as a core strategy toward a more efficient and renewable energy supply system.

In the three municipalities, also defined as national megacities, more than $95 \%$ of electricity needs to be imported from other provinces. With larger areas forming their hinterlands, the three provinces achieve much higher shares of domestic production, but the import shares still account for $77 \%$ in Hebei, $75 \%$ in Jiangsu, and $46 \%$ in Zhejiang. On the national scale, only $11 \%$ of electricity was imported in 2015. However, eastern coastal regions largely rely on energy imports from western and central China due to the limited energy resources. A detailed overview over the current power exchange situation in the study regions and China is given in Figure A5 in Appendix A.

\subsection{Characteristics of Energy Demand}

Technical and structural characteristics and the degree of efficiency are key drivers of energy demand. Among the cities and provinces considered, Beijing has the lowest share of energy consumption in industry, indicating a more service-based economy with rather low energy intensity. The economic centers Beijing and Shanghai have the highest share of energy consumption in the transport sector (rail, road, and aviation) as national and international transportation hubs. Hebei and Jiangsu, which have the highest share of energy consumption in industry, especially face the challenges of efficiency improvement, industrial upgrading, and air pollution mitigation. Industrial energy consumption of Tianjin and Zhejiang accounts for $69 \%$ and $65 \%$, respectively, similar to the national average. Figure A6 in the Appendix A shows the current energy consumption structure by sector with regional differences.

As an indicator of the status of the energy system, we present energy intensity in Figure 2, where current energy intensity by sector is calculated as a ratio between energy consumption and added value. Hebei has by far the highest energy intensity in industry (4.97 MJ/RMB), more than two times the national average (2.23 MJ/RMB). The reason behind this is high production capacity in energy, steel, and chemical industries, which were partly shifted from Beijing and Tianjin. Higher energy intensity in transportation in Beijing and Shanghai is mainly due to international flights. Tianjin has the highest energy intensity in the construction sector. Energy intensity in the service sector is similar in all regions, with a maximal value in Hebei of $0.48 \mathrm{MJ} / \mathrm{RMB}$. 

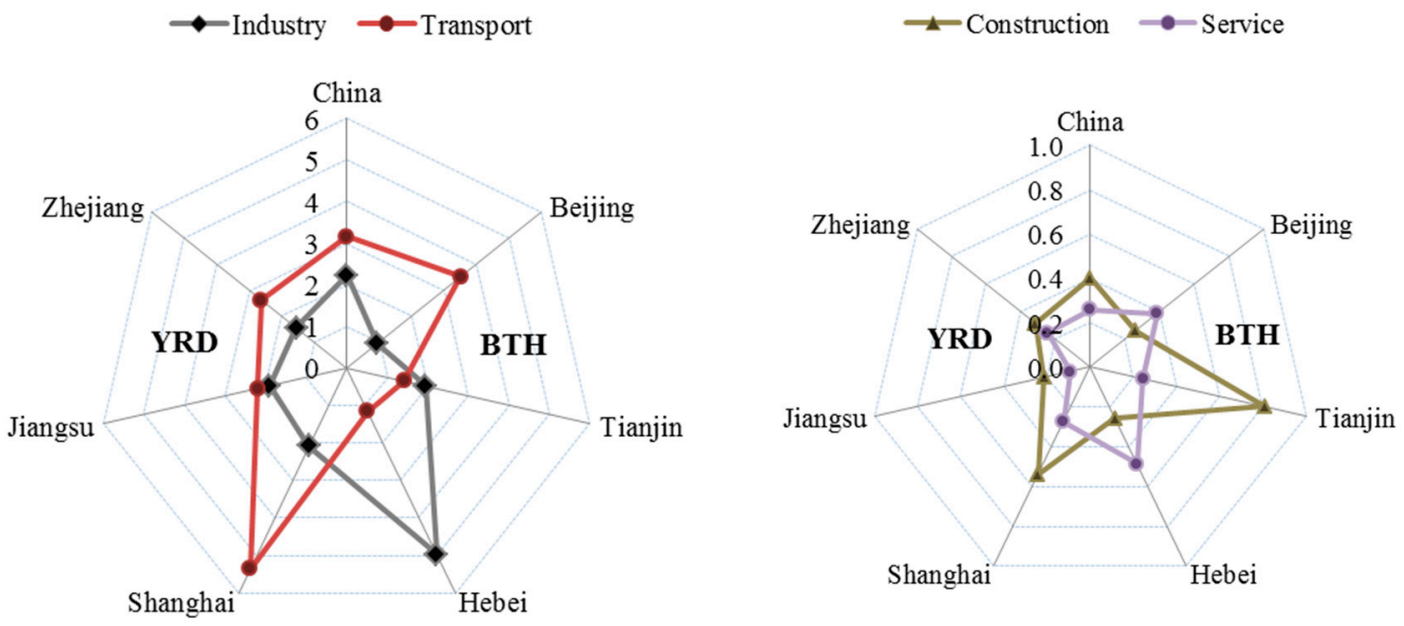

Figure 2. Energy intensity (MJ/RMB) of study regions and China in 2015 by sector (data source: China Energy Statistical Yearbook 2016 and China Statistical Yearbook 2016).

Energy intensity in the residential sector is calculated as energy consumption per capita differentiated by urban and rural areas (see Figure 3). Heating demand in winter causes higher residential intensity in BTH compared to YRD and the national average. Shanghai, Beijing, and Tianjin have the highest urban energy intensity, indicating higher living standards, and relatively high rural intensity, indicating the long commuting distances because of the large urban scale. Hebei Province has relatively high urban and rural energy intensity, although the urbanization rate is the lowest of all considered provinces. Comparing Figures A1 and A2 with Figure A3 reveals an obvious interrelation between higher shares of electricity use plus district heating and lower energy intensity. Rural areas with still considerable shares of traditional use of coal and biomass have mostly higher intensity. The differences in energy consumption structures of urban and rural areas and the ongoing urbanization process, especially in Hebei, Jiangsu, and Zhejiang, cause high uncertainty about future development; however, there is the potential for significant efficiency improvement. (Note: not all traditional energy use, like biomass, is included in the statistics.)

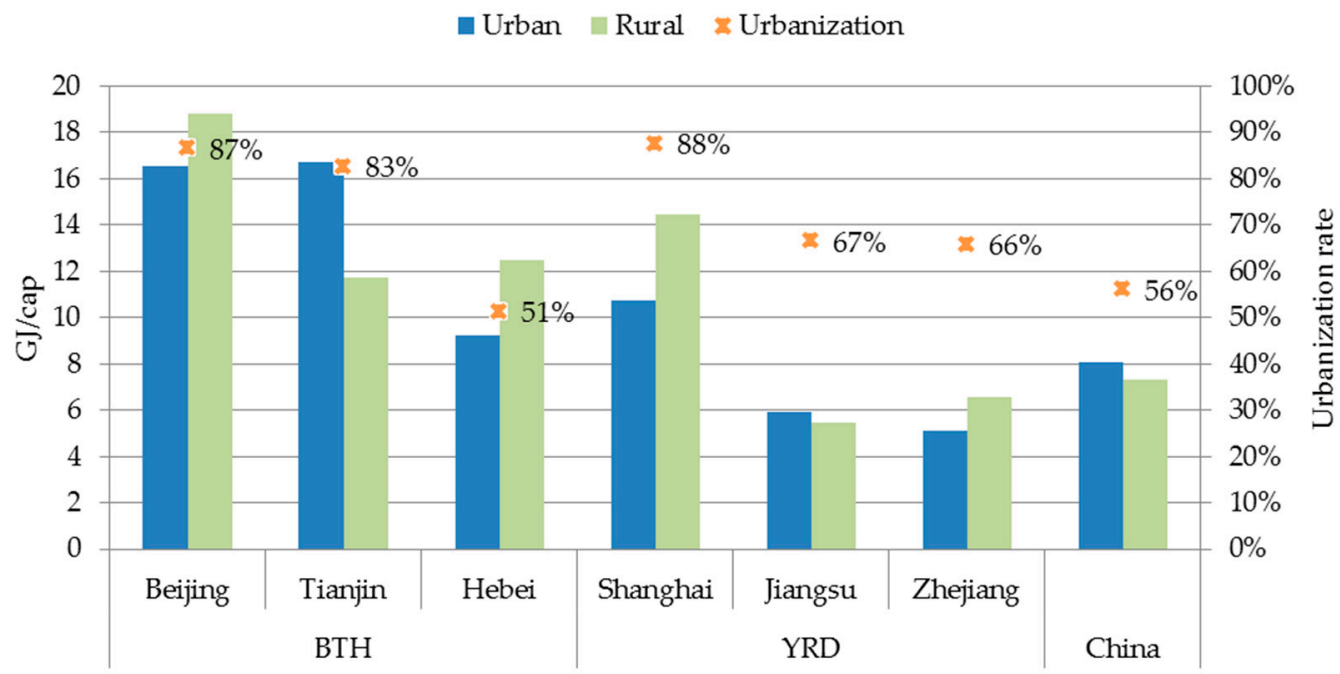

Figure 3. Energy intensity in residential sector and urbanization rate of study regions and China in 2015 (Data source: China Energy Statistical Yearbook 2016 and China Statistical Yearbook 2016).

\section{Energy Transition in China}

The goal of decarbonizing the energy system poses basically similar challenges worldwide and requires the same aspects to be analyzed and tackled with regionally adapted transition strategies and 
effective measures. The implementation of the energy system transformation has different boundary conditions in each region, thus, various possibilities and potentials need to be analyzed in order to shape the transition process successfully. In this chapter we therefore consider key challenges in regional energy system transition and provide an analysis of corresponding transition aspects and required actions.

\subsection{Key Challenges}

Based on the regional characteristics and current energy supply and demand structures described in the previous section, the challenges of regional energy system transition are identified in the following. The strong growth in energy demand and its concentration in some regions represent an extremely challenging context. Renewable energies and alternative fuels need to be further exploited for fossil fuel substitution. Besides, significant air pollution comes from transportation, especially from urban passenger mobility and interregional freight transport, but also increasing air traffic. Therefore, higher shares of electricity in the heat and transport sectors is an obvious solution, together with large RE penetration into the power sector. As RE resources are not balanced with population and economic activities, regional interconnection is a prerequisite for deep electrification and decarbonization in metropolitan regions of China. These four main challenges are further discussed in the subsections below.

\subsubsection{Efficiency Improvement}

Energy demand in China is still increasing due to urbanization, resulting in higher living standards, growing passenger traffic and car fleets, and further industrialization processes. However, the strong industrial sector with high energy intensity stands out in energy demand compared with Organization for Economic Co-operation and Development (OECD) countries. Thus using energy more efficiently must be a major target. Efficiency improvement directly influences how energy consumption control targets are achieved in various end-use sectors. Specific policies can focus on, e.g., overall energy conservation and emissions reduction, technology standards, integrated transportation system development, building energy conservation, or green building development. Existing policies usually support near-term energy-saving targets in industry, transportation, and building sectors. A successful energy system transition requires achieving high energy intensity reduction targets in the eastern coastal regions, which is especially challenging in the light of a fast economic growth rate and industrial-sector dominated economic structure.

\subsubsection{Reduction of Coal Use}

In addition to the usual challenges of maintaining the security of supply and increasing public access to clean energy, the huge increase in coal consumption during the last decade led to high $\mathrm{CO}_{2}$ emissions in China, which is a huge burden for the decarbonization process [23]. Coal reduction strategies not only aim to increase non-fossil fuel shares in the primary energy supply, but also to considerably improve air quality. In northern China, e.g., in the BTH region, heating demand in the winter season contributes to serious local air pollution, especially small coal boilers in areas without efficient district heat systems. In rural areas, space heating still relies on individual stoves supplied with briquettes and straw, which means there is huge potential to expand modern heating systems to include the use of solar and geothermal energy in the future. Shifting from coal to electric heating would enable China to integrate more electricity from wind and solar into its energy mix, under the so-called coal-to-electricity program. Under current heat zone classification, district heating is only available for the northern parts of the Huai River, as the geographical boundary of northern and southern China. Therefore, only individual units like air-conditioners and electric ventilation fans are normally used for short-time heating in the YRD region, where the temperature frequently drops below $5{ }^{\circ} \mathrm{C}$ during winter. Strategies to implement modern district energy systems but also highly efficient decentralized energy systems for heating and cooling services, using technologies such as 
combined heat and power (CHP), thermal storage, and heat pumps, need to be further explored [24] in both regions.

\subsubsection{Transport Decarbonization}

Continuous urbanization and development of road passengers and freight and air transport will further increase fuel demand and dependence on imported oil. Also, in dense urban areas, local pollution from private cars imposes serious negative effects on people and the urban environment. Urban expansion increases commuting distances and travel for leisure or business. Decarbonizing China's transport sector highly depends on further electrification and the complementary implementation of other alternative fuels such as hydrogen and biofuels, but also the development of public transport infrastructures to limit further growth of private car fleets.

\subsubsection{Multisector Electrification with Regional Integration}

The continuous urbanization process leads to growing mobility and heating/cooling demand of households. Further electrification on the supply side is thus essential to decarbonize the current coal- and oil-dominated energy system. However, integrating high shares of variable renewable energy into the future energy system needs additional infrastructures such as grid and charging technologies, transmission lines, storage, and other flexibility measures. The development of new business models could combine distributed generation systems with storage facilities and electric vehicles, which would improve system flexibility and efficiency. Deep decarbonization of energy systems therefore calls for sector coupling of electricity, mobility, and heating sectors. This strategy requires implementing suitable and efficient sector-coupling technologies, but also favorable market and other framework conditions.

Globally, installed renewable energy capacity is booming, but problems regarding grid integration have appeared due to variability of the electricity feed-in. Therefore, large amounts of electric power are curtailed to keep a real-time balance between load and generation in power systems [25]. Efficient load-balancing strategies require transregional and trans-provincial resource allocation [26]. The transmission system was originally planned to convey coal-fired electricity from coal-rich regions such as Inner Mongolia and Shanxi over moderate distances to load centers [27]. However, current transmission capacity planning aims to improve the integration of large amounts of renewable remote wind and solar capacity, to reduce high curtailment rates in some areas and to assist coal power reduction plans in eastern coastal China from other regions. A reliable power transmission infrastructure will play a crucial role in supporting continued economic expansion and China's commitment to decarbonizing the whole energy system [3]. In addition to transmission capacity expansion, planning for local storage and other flexibility measures is also a key factor in balancing variable renewable energy (VRE)-dominated energy systems.

\subsection{Transition Aspects and Required Actions}

Based on the above identified key challenges, a literature review helped to identify essential long-term transition aspects and policy intervention suggestions. A large variety of technical solutions could be addressed by policy: wind power and photovoltaics (PV) promise high potential at low cost. However, their variable supply poses challenges to load balancing in electricity grids and security of supply (see, e.g., [28,29]). Thus, dispatchable renewable power, e.g., based on hydro reservoirs, concentrating solar power (CSP) plants, or high-efficiency cogeneration plants based on biomass, will play an important role as well but is still associated with high generation costs. Flexible backup generation capacity based on gas turbines and short- to long-term power storage is expected to be the backbone of the future power system (see, e.g., [30,31]). Gas power stations could also be fueled with hydrogen or synthetic gas produced on the basis of renewable power. Synthetic fuel applications, such as hydrogen for the transportation sector, could provide flexibility in addition to storage, power transmission between regions, or demand-side management [32]. Due to high 
efficiency and no direct emissions, it seems to be common sense that electric vehicles will be the key technology in low-carbon transportation. They also offer the possibility to provide additional flexibility to the power system via controlled charging (see, e.g., [33,34]). Heat supply also needs fundamental changes that lead to high efficiency of buildings and industrial applications and the large-scale use of solar and geothermal heat. A massive implementation of solar collectors, heat pumps, and efficient cogeneration would benefit from an expansion of district heating, which could include larger heat storage and power-to-heat applications. In addition to these briefly summarized technical and structural options for the energy transition, other concepts are more or less promoted depending on national policies, such as the implementation of carbon capture and storage (CCS) or the expansion of nuclear power plants.

Decarbonizing the energy system in metropolitan regions requires the strong support of regional policy, e.g., for adjusting the economic structure, implementing new technologies and infrastructure, and reducing fossil fuels. China has strengthened its economic integration of metropolitan areas and the governance of urban agglomerations [35]. However, in general there is a need for integrated strategies considering all essential aspects of the transition process in order to define required policy actions on different administrative scales. Some of the most relevant aspects are further discussed in the following sections.

\subsubsection{Adjustment of Economic Structure and Efficiency Measures}

There seems to be a consensus in the energy systems analysis community that a reliable, binding, and courageous energy-efficiency policy is the backbone of each decarbonization pathway. Rapid efficiency improvements in all sectors are essential, especially under the continued urbanization and industrialization process in China [36,37]. Changes in the regional economic structure may support the implementation of new and more efficient techniques and processes. The enormous investments in technical and structural substitutions can only be realized through regulatory measures, economic incentives, and intensive stakeholder decision-making processes. New efficiency standards for techniques based on best available options require international agreement and regulations. Vehicle fuel economy and emission standards are a suitable measure to stimulate innovation and the replacement of internal combustion engines by more efficient electric drivetrains. In each field of action, it is important that uniform legal frameworks are established in all regions to support the development of low-carbon technologies.

\subsubsection{Control of Consumption of Fossil Fuels and Expansion of Renewables}

Reducing fossil fuels and expanding renewable energies are two sides of the same coin, but both need to be addressed by specific measures. Limiting and controlling the further consumption of coal and oil products may be an effective option; another option discussed is a general carbon tax or surcharge to increase the price of fossil fuels. Effective carbon pricing on a national and international level is seen globally as a key mechanism to support the energy system transition. On the other hand, a rapid and strong expansion of renewable energies is required for the large-scale production of power, heat, and fuels. In northern regions such as BTH, where space heat demand is high in the winter season, coal substitution needs to be done with regionally available renewable energies such as biomass, solar, geothermal, and wind power. Natural gas combustion as a substitute for coal burning can be a bridging technology that can be converted to the use of biogas and synthetic gas in a later transition phase. All strategies for the expansion of renewable energies require sufficiently high economic incentives, competitive RE industries, and investment security. Favorable regulatory frameworks and interventions such as renewable portfolio standard (RPS), promotion of electric vehicles and alternative fuels, stable energy market design, and finance mechanisms are preconditions for large investments in new technologies and infrastructures such as transmission lines and storage. Financial markets to support the development of renewable energy expansion need to be designed with regulation support [3,38]. Cost reduction of low-carbon technologies is another key aspect to 
guarantee a cost-effective and dynamic energy system transition. Research and development funding and promotion of innovation on the production side are essential to achieve further significant cost reduction and possibly even disruptive technology implementation.

\subsubsection{Sector Coupling and Supporting Infrastructure}

The decarbonization of heating and the transport sector in particular poses huge challenges in the transition of all energy systems. These targets need support from a widely decarbonized power sector via electrification of supply technologies. Sector coupling adds further power demand and complexity to the transformation of fossil fuel-based power supply systems and the implementation of renewable energies [36]. However, it is a key strategy to integrate large shares of renewable energy into these sectors, to make use of flexibility options across the energy system, and to achieve a cost-effective power supply system. In addition to direct electrification by power-to-heat via electric boilers and heat pumps and the implementation of electric vehicles in transportation, the power-to-gas option enables the production of synthetic gas (hydrogen or methane) using renewable electricity and electrolyzers with gas storage [39]. With further processing routes, even liquid synthetic fuels for transport could be produced. In order to deal with the fluctuating characteristics of renewable energies, additional expansion of storage systems, transmission grids, and other flexibility options, such as smart grids and demand-side measures, is required. Implementing these supporting infrastructures necessitates huge investments, and therefore new business concepts and suitable market conditions. A flexible power-driven operation of combined heat and power plants with supervisory control and increased use of heat storage as well as the flexible use of heat pumps with storage are also important in sector coupling and improving system flexibility.

\subsubsection{Public Acceptance and Awareness}

Public acceptance is an important precondition for long-term energy system transition. It involves different market, sociopolitical, and community issues [40-42], especially for investment in and construction of energy-related infrastructure [43]. Public involvement in the decision-making process may be an important aspect, but may not necessarily lead to higher local acceptance. However, opportunities for (economic) participation, transparent information, and fair sharing of the burden help to avoid local rejection of projects. Expanding onshore wind farms and transmission lines usually poses the highest risk regarding local acceptance.

The market development of low-carbon technologies and efficiency improvement also relies on public awareness. Improving public awareness, e.g., by active discourse and communicating the societal long-term targets of energy transition, contributes to public acceptance. Public consensus, constructive and fact-based discourse in the media, and political stability regarding the targets are preconditions for a successful transition process. Transforming the energy system toward low carbon pathways also requires major sociotechnical changes and a paradigm shift, which affects not only technology itself, but also business models and institutions [44-46].

\subsubsection{Governance Strategies}

Beyond technical aspects, research is increasingly focusing on governance as a success factor of energy system transition [47,48]. New analytical frameworks are developed to cover the necessary institutional change and address stakeholder integration [49]. Experience to date in various countries shows that comprehensive regional planning and energy-, sector-, and technology-specific planning are important strategies for energy policy [50,51]. Continuously monitoring the achievements in light of the targets and using milestones under consistent legal and policy conditions can guarantee an effective energy transition [50,52]. Thus, well-founded energy transition management needs to navigate, i.e., continuously identify the most favorable solutions and effective measures in the course of the transition process. Long-term scenario analyses help to identify robust and/or optimal transition pathways to reach certain economic, societal, environmental, and climate goals [53]. All of 
the mentioned transition aspects and related measures require the support of specific or integrated policies across administrative levels.

\section{Current Policy}

National policies and related targets have obvious impacts on the progress of energy system transition globally $[54,55]$. Some of the identified challenges need a national (or even international) perspective, especially regarding the implementation of carbon pricing and market mechanisms. Others, in contrast, need to be addressed at the regional and local levels where the implementation of policies and direct investments take place, thus regional coordination with a set of specific and concrete policies is highly needed that allow the integration of different stakeholders, decision-makers, and regulators. The Chinese Renewable Energy Outlook [3] advocates a strong role of regional policy in the energy transition, especially for tapping regional synergies between demand and supply and ensuring public acceptance of the transition. In the following, currently available short-term policies at different administrative levels of China are analyzed in detail with regard to the identified transition challenges in selected metropolitan regions.

\subsection{National Level}

Since the 12th Five-Year Plan (2011-2015), China's economic policy has prioritized a transition from energy-intensive growth based on heavy industry, exports from manufacturing, and high investment to a more balanced economy. This is characterized by slower growth, an increasing role of services and domestic consumption, and a focus on innovation and low-carbon technologies [3]. The latest general energy development targets for 2020 were set in June 2014, when the National Energy Development Strategy and Action Plan (NDSAP) for 2014 to 2020 released by the General Office of the State Council (GOSC) came into force [56]. It provided fundamental guidance for the 13th Five-Year energy-related plans two years later, as shown in Table 2.

The special 13th Five-Year Energy Plan, released in December 2016, further concretized general climate- and energy-related targets (see Table 3). It therefore serves as an improved guideline for policy-making, public investment, and project planning in the energy sector. The specific energy plan aims to optimize the energy mix and promote low-carbon energy development. The diversification of existing energy resources and the deployment of new sources are important for renewable energy policy implementation $[57,58]$. The national targets for non-fossil fuels in the primary energy mix are $15 \%$ by 2020 and $20 \%$ by 2030 . Regarding the 12th Five-Year Plan (2011-2015), China has failed to comply with the target for offshore wind development. With more efforts to solve industrial, institutional, and technical barriers, there is more emphasis on offshore wind development in the 13th Five-Year Plan.

The described energy planning is binding only on the national level. However, those targets need to be broken down to the regional level, where technology implementation and investment decisions happen. Therefore, the regions are supposed to further concretize, plan, and steer the transition process with regard to the overall targets. 
Table 2. Overview of national energy development-related policies toward 2020.

\begin{tabular}{|c|c|c|c|c|c|c|c|}
\hline Release Date & 7 June 2014 & 11 January 2016 & March 2016 & 7 November 2016 & 10 December 2016 & 26 December 2016 & 30 December 2016 \\
\hline \multicolumn{8}{|c|}{ 13th Five-Year National Plans and Guidelines for: } \\
\hline Policy & $\begin{array}{l}\text { Energy Development } \\
\text { Strategy \& Action Plan } \\
\quad(2014-2020)\end{array}$ & $\begin{array}{l}\text { Renewable Vehicles: } \\
\text { Promotion of } \\
\text { Infrastructure \& } \\
\text { Vehicles (2016-2020) }\end{array}$ & $\begin{array}{l}\text { Economic \& Social } \\
\text { Development } \\
\text { (2016-2020) }\end{array}$ & $\begin{array}{l}\text { Power Development } \\
\text { Plan (2016-2020) }\end{array}$ & $\begin{array}{l}\text { Renewable Energy } \\
\text { Development Plan } \\
\quad(2016-2020)\end{array}$ & Energy Plan (2016-2020) & $\begin{array}{l}\text { Ocean Energy Plan } \\
\quad(2016-2020)\end{array}$ \\
\hline \multirow[t]{2}{*}{ Policy maker } & $\begin{array}{l}\text { Office of the State } \\
\text { Council }\end{array}$ & \multicolumn{5}{|c|}{ National Development and Reform Commission } & $\begin{array}{l}\text { State Oceanic } \\
\text { Administration }\end{array}$ \\
\hline & & $\begin{array}{c}\text { Ministries of } \\
\text { - Finance } \\
\text { - Science \& Technology } \\
\text { - Industry \& Information } \\
\text { - Energy }\end{array}$ & & $\begin{array}{c}\text { National } \\
\text { Administration of } \\
\text { Energy }\end{array}$ & & $\begin{array}{l}\text { National Administration of } \\
\text { Energy }\end{array}$ & \\
\hline
\end{tabular}

Table 3. Key national energy targets by $2020[59,60]$.

\begin{tabular}{|c|c|c|c|c|c|}
\hline Aspect & Parameter & Unit & Statistics 2015 (2017) & Target 2020 & Average Annual Change Rate (\%) \\
\hline \multirow{7}{*}{ Electricity consumption } & Total installed capacity & GW & $1530(1800)$ & 2000 & 5.5 \\
\hline & Transmission of electricity from west to east & GW & 1400 & 2700 & 14 \\
\hline & Total electricity consumption & $\mathrm{TWh} / \mathrm{yr}$ & 5690 & $6800-7200$ & $3.6-3.8$ \\
\hline & $\%$ of electricity in final energy consumption & $\%$ & 25.8 & 27 & 1.2 \\
\hline & $\%$ of non-fossil fuels for power generation & $\%$ & 12 & 15 & 3 \\
\hline & Average annual consumption per capita & $\mathrm{kWh} / \mathrm{cap}$ & 4142 & $4860-5140$ & $3.3-4.4$ \\
\hline & Fuels replaced by electricity & $\mathrm{TWh} / \mathrm{yr}$ & - & 450 & - \\
\hline \multirow{13}{*}{$\begin{array}{l}\text { Power generation structure, } \\
\text { installed capacity }\end{array}$} & Conventional hydro power & GW & $297(341)$ & 340 & 2.8 \\
\hline & Pumped hydro storage & $\mathrm{GW}$ & 23 & 40 & 11.7 \\
\hline & Nuclear & $\mathrm{GW}$ & $27(35.8)$ & 58 & 16.5 \\
\hline & Wind & $\mathrm{GW}$ & $131(164)$ & 210 & 9.9 \\
\hline & Solar & $\mathrm{GW}$ & $42(130)$ & 110 & 21.2 \\
\hline & Coal & $\mathrm{GW}$ & 900 & $<1100$ & 4.1 \\
\hline & Natural gas & $\mathrm{GW}$ & 66 & 110 & 10.8 \\
\hline & Non-fossil fuels & GW & 520 & 770 & 9.6 \\
\hline & Share of fossil fuel power plants & $\%$ & 65 & 61 & -4 \\
\hline & Share of coal power plants & $\%$ & 59 & 55 & -4 \\
\hline & Share of non-fossil fuel power plants & $\%$ & 35 & 39 & 4 \\
\hline & Share of gas power plants & $\%$ & - & $>5$ & - \\
\hline & Share of non-fossil fuel electricity generation & $\%$ & - & 31 & - \\
\hline \multirow{3}{*}{ Efficiency } & Newly installed coal power plants & $\mathrm{gCE} / \mathrm{kWh}$ & - & 300 & - \\
\hline & & $\mathrm{kJ} / \mathrm{kWh}$ & - & 10.24 & - \\
\hline & Existing coal power plants & $\mathrm{gCE} / \mathrm{kWh}$ & 318 & $<310$ & -1.6 \\
\hline Electric vehicles (EVs) & Public charging infrastructure & - & - & for 5 million $\mathrm{EVs}$ & - \\
\hline
\end{tabular}




\subsection{Provincial/Municipal Level}

The 13th Five-Year Provincial and Municipal Renewable Energy Development Plans were released by the respective provincial and municipal Development and Reform Commissions. In general, no harmonized policy for the energy sector exists on the regional level; instead, the provinces and municipal cities set their own plans. The basic direction is set by the general plans, providing guidelines for provincial and municipal economic and social development, which were released from January to November 2016. The next subsections give a detailed overview of available plans for the two regions, disaggregated by the three provinces and three provincial-level municipal cities.

\subsubsection{Beijing-Tianjin-Hebei Region}

The provincial-level 13th Five-Year Renewable Energy Development Plan was released by the end of 2016 in the BTH region. The plan proposes that total renewable energy use and installed renewable energy capacity in the power sector should reach 1000 PJ and $45 \mathrm{GW}$, respectively, by 2020. In separate plans for renewable energy development (see Table 4), regional integration and cooperation have been further emphasized as important aspects for regionally balanced development. Electrification was addressed as a key measure to improve air quality, thus 12 interregional transmission lines have been approved to be built in order to get access to the western RE resources [60].

Policies in the BTH region are disaggregated to the level of individual technologies or subcategories such as straw use. All three provinces address the issue of renewable heat supply by targets for specific technologies within special plans for renewable energy development (see Table 4). Hebei Province specifically mentions solar collectors and geothermal energy for heating. Other renewable options addressed by policy plans are biofuels and offshore wind. In Hebei Province there is also a target for electricity storage, considering the future challenges for a power system with high shares of VRE. Within this context, Hebei Province plans to improve its ability to control curtailment rates from wind power and PV below 10\%. Both Tianjin and Beijing also plan to further increase their ability to import electricity from the surrounding renewable energy abundant regions. Beijing has a target to import 10 TWh per year in renewable electricity by 2020 , accounting for $50 \%$ of its total imported electricity. Its power dispatch challenges due to VRE will be made the first priority. Tianjin plans to cooperate more with Hebei Province and Inner Mongolia, which are characterized by high wind potential. This is supposed to increase electricity imports to Tianjin to around 6 TWh per year by 2020 .

During the energy transition process, the plans for Beijing and Tianjin strive for regionally integrated development together with Hebei Province. The plans also include utilizing the import potential from other surrounding regions, such as Inner Mongolia, especially for renewable electricity from wind and solar energy. At the same time, new transmission lines are planned to solve curtailment problems that arose due to the fast expansion of wind power plants [61]. In Tianjin, imported electricity by 2020 would account for $60 \%$ of its total demand (see Table 4 ).

The BTH region also sets targets for geothermal energy deployment as an option to replace coal for heating. Currently there are 48 geothermal fields in the BTH region, with 10 in Beijing, 8 in Tianjin, and 30 in Hebei Province. The annual exploitable geothermal energy accounts for $10^{4} \mathrm{PJ}$. Based on the existing planning for geothermal development in the region, this technology is expected to play a key role in replacing coal consumption, especially for heat supply.

Based on the adapted national offshore targets, the 2020 offshore development targets for Hebei Province and Tianjin were set at $800 \mathrm{MW}$ and $290 \mathrm{MW}$, respectively (see Table 4). In Hebei Province, the renewable energy plan mentions an exploitable potential of $79 \mathrm{GW}$ onshore and $10 \mathrm{GW}$ offshore. In addition, $90 \mathrm{GW}$ of biomass-based power plants are mentioned, which can provide backup capacity and flexible generation. In Beijing, a specific integrated transportation development plan was released, similar to Shanghai and Zhejiang Province, which is discussed in the next subsection. 
Table 4. Energy transition-related targets in Beijing, Tianjin, and Hebei Province.

\begin{tabular}{|c|c|c|c|c|c|}
\hline Province & & & Beijing & Tianjin & Hebei \\
\hline \multirow{3}{*}{ Related policy } & \multirow{3}{*}{ 13th Five-Year Plans for: } & & Renewable Energy Development & Renewable Energy Development & Economic \& Social Development \\
\hline & & & & & Energy Development \\
\hline & & & & & Renewable Energy Development \\
\hline Policy maker & & & Development \& Reform Commission & Development \& Reform Commission & Development \& Reform Commission \\
\hline Release date & & & 26 September 2016 & 19 December 2016 & 14 October 2016 \\
\hline Aspects & Main indicators & Unit & 2020 & 2020 & 2020 \\
\hline \multirow{3}{*}{ Primary energy } & From renewable & $\mathrm{PJ} / \mathrm{yr}$ & 181 & 147 & 674 \\
\hline & Local renewable & $\mathrm{PJ} / \mathrm{yr}$ & & 94 & \\
\hline & Renewable share & $\%$ & 8 & 4 & 7 \\
\hline \multirow{3}{*}{ Electricity generation } & Coal share & $\%$ & $<10$ & & \\
\hline & Local RE electricity & $\mathrm{TWh} / \mathrm{yr}$ & & 4 & \\
\hline & Renewable share & $\%$ & & 10 & $>13$ \\
\hline \multirow{2}{*}{ Electricity generation } & Imported RE electricity & $\mathrm{TWh} / \mathrm{yr}$ & 10 & 6 & \\
\hline & Wind & $\mathrm{TWh} / \mathrm{yr}$ & & & 40 \\
\hline \multirow{2}{*}{ Installed RE capacity } & Total RE installed capacity & GW & 2 & 2.12 & \\
\hline & Renewable share & $\%$ & & 10 & $>41$ \\
\hline \multirow{5}{*}{ Installed RE capacity } & Solar & GW & 1.16 & 0.8 & \\
\hline & Wind & GW & 0.65 & 1.16 & 20.8 \\
\hline & Offshore & MW & & 800 & 290 \\
\hline & Biomass (waste/straw) & MW & 350 & $155(120 / 35)$ & \\
\hline & Hydro & MW & & 5 & \\
\hline Storage & Pumped storage & GW & & & $>16$ \\
\hline \multirow{3}{*}{ Heating supply (area) } & Renewable heating & $\mathrm{km}^{2}$ & & & 160 \\
\hline & Geothermal (deep/shallow) & $\mathrm{km}^{2}$ & 70 & $51(35 / 16)$ & \\
\hline & Solar heating & $\mathrm{km}^{2}$ & 9 & 20.4 & 16 \\
\hline Fuel & Biomass for fuel & $\mathrm{PJ} / \mathrm{yr}$ & & 23 & \\
\hline
\end{tabular}




\subsubsection{Yangtze River Delta Region}

Energy-related policy in the YRD region is an integral part of the overall development plans. Table 5 gives an overview of energy-related targets and corresponding policy plans in the YRD region. While a specific energy plan is not yet available in Shanghai, at least renewable fuels and $\mathrm{CO}_{2}$ reduction are already addressed via the regional policy. Similar to the BTH region, the regional integrated transportation system is enhanced in Shanghai by the 13th Five-Year Plan, promoting the expansion of highways, railways, and public bus lanes.

In contrast to Shanghai, Jiangsu Province developed a special 13th Five-Year Plan for Power Development and Renewable Vehicle Development Actions, released at the end of 2016. The first plan included a limited set of renewable energy technologies: biomass, PV, and wind [62]. The second plan aimed for market development of electric and fuel cell vehicles and was released at the end of 2016 [63]. In 2009, the province announced it was building an offshore "three gorges" project (in the style of the Three Gorges hydro dam project in China) with a target of $10 \mathrm{GW}$ installed capacity by 2020. The Power Development Plan also addresses the aspect of electrification in the transport sector, by targeting increased electric rail traffic. This provides an interrelation with the region's Plan for Integrated Transportation Development, released in October 2017 [64]. The development of efficient combined heat and power $(\mathrm{CHP})$ production is also included qualitatively as the promotion of residential $\mathrm{CHP}$ projects in northern Jiangsu Province. It prioritizes industrial CHP for economic development zones and gradual substitution of coal CHP by natural gas in urban areas in the southern part of the province. Expansion targets for renewable power plants are complemented by the solar plan for both utility and decentralized applications, especially for rooftop distributed PV. The promotion of wind power is focused on offshore, but also includes onshore for middle to low wind speed resources. In addition, biomass expansion plans mainly focus on residues, such as straw and municipal and rural waste.

Energy policy in Zhejiang Province also relies on its overarching plan for economic and social development. However, this plan is rather specific with regard to energy targets, but less focused on renewable energy. In comparison with the other energy plans, the Zhejiang Province plan also includes a nuclear target of $9 \mathrm{GW}$, with $5 \mathrm{GW}$ under construction. It also focuses on energy consumption and providing additional services to the population by promoting electrification in rural areas to replace fossil fuels.

Comparing the BTH and YRD regions, it becomes clear that there is no common standard for addressing energy decarbonization in China on the regional level. From detailed insight into energy policy, we identified a variety of short-term targets addressing the immediate specific needs of each province (or provincial-level city). While the principle of subsidiarity is a valuable asset for the adoption of regional policies, it needs to be complemented by a mechanism that ensures a consistent transition process between regions in the long term.

\subsection{Regional Level}

Regional policy makers are aware of the need to cooperate in the field of regional development and to harmonize policies in metropolitan regions. There are more and more collaborative interactions between urban and regional energy governance related to the energy transition, with diverse and dynamic organizational responses $[65,66]$. Policy makers are advised to intensify regional integration in order to lower the barriers to improved energy and $\mathrm{CO}_{2}$ emissions performance [67]. This addresses especially administrative and policy barriers, which are even more important than geographical distance [68]. Mainly air pollution issues currently drive regional integrated strategic development, and all stakeholders should be aware that an integrated energy system transition is required beyond the single municipal or provincial level [69]. Therefore, Beijing, Tianjin, and Hebei Province together are one of the first regions developing a joint collaborative development plan, as presented in Table 6. China's first regional development plan integrating several provinces was released at the end of 2016. It aims to promote regionally balanced development and regional integration in terms of finding effective solutions to air pollution, transportation, energy, and $\mathrm{CO}_{2}$ emissions and other issues. 
Table 5. Energy transition-related targets in Shanghai, Jiangsu, and Zhejiang Province.

\begin{tabular}{|c|c|c|c|c|c|}
\hline Province & & & Shanghai & Jiangsu & Zhejiang \\
\hline \multirow{2}{*}{ Related policy } & \multirow{2}{*}{ 13th Five-Year Plans for: } & & Economic \& Social Development & Economic \& Social Development & Economic \& Social Development \\
\hline & & & Energy development & Power Development & \\
\hline Policy maker & & & City government & Province government & Province government \\
\hline Release date & & & January 2016 & 30 March 2016 & February 2016 \\
\hline Aspects & Main indicators & Unit & 2020 & 2020 & 2020 \\
\hline GDP & Annual growth rate & $\%$ & 6.5 & 7.5 & \\
\hline Population & Total (urban \%) & Mill. & $<25$ & $(67 \%)$ & \\
\hline \multirow{6}{*}{ Energy supply } & Primary energy & $\mathrm{PJ} / \mathrm{yr}$ & 3663 & 11,723 & 6448 \\
\hline & Supply capacity of natural gas & $\mathrm{km}^{3}$ & 10 & & \\
\hline & Increase in natural gas supply & $\%$ & 12 & & \\
\hline & Share of non-fossil/clean energy & $\%$ & & 10 & $20 / 32.5$ \\
\hline & Share of renewable energy & $\%$ & & & 12.5 \\
\hline & Renewable energy total & $\mathrm{PJ} / \mathrm{yr}$ & & & 945 \\
\hline \multirow{5}{*}{ Installed capacity } & Total & GW & & 130 & 94 \\
\hline & Nuclear & GW & & & \\
\hline & Wind (onshore and offshore) & GW & & $8-10$ & 9 \\
\hline & PV & GW & & $8-10$ & 6 \\
\hline & Biomass (waste and straw) & GW & & 1.5 & \\
\hline \multirow{2}{*}{ Transportation } & Modal share of rail in city & $\%$ & 60 & & \\
\hline & Share of renewable fuels & $\%$ & 50 & & \\
\hline $\mathrm{CO}_{2}$ emissions & & Bill. tons & $<0.25$ & & \\
\hline
\end{tabular}


Table 6. Energy transition targets related to regional integrated development in Beijing-Tianjin-Hebei region.

\begin{tabular}{|c|c|c|c|c|}
\hline Related policy & \multicolumn{4}{|c|}{$\begin{array}{l}\text { 13th Five-Year Plan for Beijing-Tianjin-Hebei Region Collaborative Development } \\
\text { 13th Five-Year Plan for Beijing-Tianjin-Hebei Region Economic and Social Development } \\
\text { 13th Five-Year Plan for Beijing-Tianjin-Hebei Region Renewable Energy Development }\end{array}$} \\
\hline Policy maker & \multicolumn{4}{|c|}{ National Development and Reform Commission (NDRC) } \\
\hline Release date & \multicolumn{4}{|l|}{25 November 2016} \\
\hline Aspect & Main indicators & Unit & 2020 & Remarks \\
\hline GDP & Average annual growth rate & $\%$ & 7 & \\
\hline Population & Urbanization rate & $\%$ & 60 & \\
\hline Industry & Industry shifting & & & $\begin{array}{l}11 \text { municipal level cities in Hebei } \\
\text { Province and special node cities of } \\
\text { Dingzhou and Xinji have special } \\
\text { roles in BTH collaborative } \\
\text { development regarding industrial } \\
\text { shifting from capital city of Beijing }\end{array}$ \\
\hline Transportation & \multicolumn{4}{|c|}{ Remove non-capital city functions to improve efficiency and sustainability } \\
\hline Air quality & \multicolumn{4}{|l|}{ Solve regional air pollution problems } \\
\hline RE development & $\begin{array}{c}\text { Total exploited RE energy } \\
\text { Share of RE in total energy consumption } \\
\text { RE installed capacity within city } \\
\text { Share of RE in installed capacity within } \\
\text { city }\end{array}$ & $\begin{array}{c}\mathrm{PJ} / \mathrm{yr} \\
\% \\
\mathrm{GW} \\
\%\end{array}$ & $\begin{array}{c}181.7 \\
>8 \\
2 \\
15\end{array}$ & $\begin{array}{l}\text { Newly installed capacity mainly } \\
\text { focused on RE }\end{array}$ \\
\hline $\begin{array}{l}\text { Installed RE } \\
\text { capacity }\end{array}$ & $\begin{array}{l}\text { Total RE } \\
\text { Wind } \\
\text { Offshore wind } \\
\text { PV } \\
\text { Biomass }\end{array}$ & $\begin{array}{l}\text { GW } \\
\text { GW } \\
\text { GW } \\
\text { GW } \\
\text { MW }\end{array}$ & $\begin{array}{c}45 \\
10.7 \\
1.09 \\
3.09 \\
667\end{array}$ & \\
\hline $\begin{array}{l}\text { Total exploited and } \\
\text { consumed RE }\end{array}$ & & $\mathrm{PJ} / \mathrm{yr}$ & 1002 & \\
\hline
\end{tabular}

As can be seen from the joint regional development plan of the BTH region, the demand for integrated energy system planning is already addressed here. This plan integrates all three provinces into a collaboration and considers specific issues referring to energy demand and supply, such as transport and industry development, as well as renewable power plants (see Table 6). In addition, the regional plan for geothermal heating and cooling in BTH has a target of covering $440 \mathrm{~km}^{2}$ heating area in 2020. With these actions implemented, the expected $\mathrm{CO}_{2}$ reduction would be 7 million tons in the BTH region [70,71]. The YRD region also features a variety of development trends connected to economic and energy transition: polycentric agglomerated urbanization, industrial upgrading [72], and infrastructure development for transportation [73] are also under process. These dynamic developments within the region demand an integrated assessment instead of analyses of single metropolitan cities or provinces. However, for the YRD region, no integrated renewable energy-related plan exists so far. Therefore, the BTH regional development plan is a showcase for regional integration in terms of promoting low-carbon transition pathways.

Some efforts are already under way to integrate policy across regions, especially for the power and transport sectors. One example of integrated planning in the transportation sector is the discussion of regional railway and highway plans. In both the BTH and YRD regions, the transport system is a major challenge that needs more integrated approaches in the future to overcome previous administrative barriers.

\section{Policy Implications}

In the following, we analyze how well the four challenges of efficiency improvement, coal reduction, transport decarbonization, and electrification/sector coupling and five identified transition aspects with required measures are met by these policies. In addition, we compare the near-term policy targets with long-term transition scenarios for China. 


\subsection{Strengths and Shortcomings of Existing Policies}

Current national and regional policies have already addressed the reduction of coal consumption. The national and provincial air pollution action plans demand peak coal consumption before 2020 in the BTH and YRD regions [74]. Therefore, provinces in BTH have set absolute coal consumption reduction targets and provinces in YRD have defined negative growth targets by 2017. Recently, the CREO concretized a possible decarbonization strategy combining significant reduction of coal and deployment of renewable energies. This can provide a sound basis for policy advice on all administrative levels, reflecting the long-term perspective of the energy system transformation.

Policies and regulations have tried to establish stable and attractive market conditions for at least some new technologies and to reduce investment risks and lower the cost of financing. To achieve this on a large scale, economic incentives such as electricity feed-in tariffs and subsidies for efficiency improvement from both national and local governments were implemented. Current policy also supports the deployment of wind and solar energy at sites with lower potential by higher feed-in tariffs and renewable portfolio standard (RPS) policy, which defines a minimum provincial-level penetration of non-hydro renewable energy for power generation [75]. Besides national distributed $\mathrm{PV}$ on a grid subsidy of $0.42 \mathrm{RMB} / \mathrm{kWh}$, Shanghai and Zhejiang Provinces also provide an additional $0.25 \mathrm{RMB} / \mathrm{kWh}$ and $0.1 \mathrm{RMB} / \mathrm{kWh}$, respectively, to promote local solar penetration, even under relative limited land availability and lower solar irradiation compared to western China.

Short-term targets for the heating sector exist mainly for the northern region of BTH, which has significant heat demand during wintertime. The short-term targets already address the further development of solar and geothermal energy use and promote the decarbonization of cogeneration plants as the most important options on the supply side. In Shanghai, pilot programs to integrate RE into buildings are supported by national and local funding; subsidies of $60 \mathrm{RMB} / \mathrm{m}^{2}$ are provided to promote the use of solar and geothermal energy for heat supply and $150 \mathrm{RMB} / \mathrm{m}^{2}$ for window efficiency improvement [76]. In Tianjin, $45 \mathrm{RMB} / \mathrm{m}^{2}$ subsidies from both national and local funding are provided for efficiency improvement in the building sector, such as insulation materials and smart meter installations [77].

The implementation of favorable market conditions is above all a task at the national level. In addition, a long-term carbon price appears to be necessary, which still leads to affordable energy prices but has a real impact on investment decisions. Pilot carbon cap-and-trade programs started in five municipalities (including Beijing, Tianjin, and Shanghai) and two provinces in 2013 to develop and test different trading modes, and a cross-provincial program in BTH and the Shanxi-Inner Mongolia-Shandong region was launched [78]. By the end of 2017, a national carbon trading system was launched for the power sector [79], and more sectors are expected to be included by 2020, according to "three-year road map" of the National Development and Reform Commission (NDRC).

The policy stakeholders are aware that it is important to deal with fluctuating characteristics of VRE technologies and implement storage technologies and other flexibility measures. However, there is not yet much activity on the regional level to further develop concepts and implement prototype plants for load balancing. Their implementation needs market conditions for promising favorable business cases as well. Development of the power transmission system is aimed at linking the rich RE resources of western and northern regions with the demands of eastern coastal regions of China.

The current renewable vehicle-related policies are focused not only on supporting the development of the industry itself, but also on shifting transportation modes. Important strategies include prioritizing the development of public transportation, prioritizing railway development instead of road transportation, and encouraging low carbon mobility such as bicycles together with new business models of bicycle sharing in main cities as a connection to public stations. All Chinese provinces already have ambitious projects for the promotion of electric vehicles, with a focus on public transportation and the buildup of public charging infrastructure. Due to serious air pollution in all urban cities, China pursues its EV strategy on both the national and local level. The Chinese government offers outright subsidies for EV buyers, exempts electric and other "new energy" vehicles 
such as hydrogen fuel-cell vehicles from purchase tax, and demands a defined share of low-emission vehicles from all car manufacturers that want to be active in the Chinese market. Until 2014, electric vehicles were not common on Chinese roads; however, during 2015 and 2016 the market increased rapidly, so that China has now the world's biggest market for plug-in vehicles. According to the China Association of Automobile Manufacturers, more than 500,000 plug-in vehicles were sold in China in 2016, of which more than 400,000 were battery electric vehicles [80]. The overall EV stock reached around 1 million vehicles, thus China is on the way to meeting its 2020 target. How far this will also lead to target-oriented long-term development cannot easily be assessed, because it strongly depends on the overall development of mobility behavior and demand in Chinese society.

Regarding the governance aspect, the policy review showed that, besides the National Energy Administration, there are at least three ministries directly involved. For example, the Ministry for Housing and Construction (MHC) is in charge of building sector efficiency improvement; geothermal energy development needs support from the Ministry of Land and Resources (MLR); and the Ministry of Industry and Information Technology (MIIT) is responsible for RE industry development. At the moment, the State Council is in charge of key national energy decarbonization policies, such as energy conservation and emission reduction; integrated transportation system development; guidance and incentive policies for promoting electric vehicles, alternative fuels, and charging infrastructure; and the air pollution prevention and control action plan. Thus, structures and processes for integrated strategies across different fields of action exist, at least on the national level. However, there still seems to be no integrated regional energy policy under the current national decision- and policy-making system. This endangers, above all, the regionally coordinated infrastructure development and effective sector coupling that are highly needed for deep decarbonization of the energy system. The eastern coastal metropolitan regions of China especially need integrated strategies to cope with limited RE resources, efficiency improvement, and energy demand control targets. New mechanisms are required to establish cooperation between the agglomerations, nearby hinterlands, and remote RE-abundant regions. Important national framework conditions of such regionally integrated strategies could be RE-oriented energy markets, a $\mathrm{CO}_{2}$ trading or tax system, and promotion schemes for technology implementation and integrated transportation systems.

Besides existing policies, specific energy-focused plans considering local characteristics and conditions are also needed, especially to concretize the long-term vision of energy transition. In addition, for both regions, the integration does not yet cover the whole energy system and all technologies required. While the BTH region initiatives can serve as a model for increased interprovincial cooperation, the temporal perspective is too short and needs to be extended to convincingly address energy decarbonization in the context of national and international targets.

Energy policies need to provide regulatory options and instruments to tackle the challenges of the energy transition by improving transition planning and management. China's administration addressed these challenges in the latest Five-Year Plans. Compared with national development plans for 2020, the special plans on the level of provinces, municipal cities, and regions are less systematic. Also, the consistency of assumed interrelations among different sectors, technologies, and social and economic developments are not clear from these plans. Within the two regions considered, a strong heterogeneity in energy policy exists regarding policy makers and specific targets. While in the BTH region policies are driven by the National Development and Reform Commission, the energy plans in the YRD region are released by provincial governments. Although all provinces focus their policies on renewable energies, there is not a joint set of indicators and measures that could help to coordinate the policies within or across regions.

Regional integration is a prerequisite to achieving the essential technical and structural changes needed. However, this requires a deeper understanding of interdependencies and connections among the various current plans made by different administration levels and ministries. 


\subsection{Implications for Long-Term Targets}

Long-term strategies for energy system transition have to cope with large uncertainties regarding the development of the society, the economy, and relevant technologies and their implementation. Model-based analysis is usually applied to guide the decision-making process. Several representative examples of such studies exist following different approaches for scenario building $[2,8,11,81,82]$. Such studies show that alternative technical and structural options could be key elements of long-term transition pathways.

Some important options and aspects mentioned in Section 4 and related measures and developments are already targeted in current short-term policy plans, with the potential to further concretize and enhance them within a regionally integrated low-carbon transition pathway. One obvious issue is the further promotion of renewable energy, which covers most available technologies, including offshore wind and biomass. However, it seems to be unclear whether expansion rates are already in line with long-term national decarbonization targets. As an example, average annual wind power installation between 2015 and 2020 derived from the regional plans ranges between $4.2 \mathrm{~W}$ (Beijing) and $28 \mathrm{~W}$ (Zhejiang) per year and per capita. The national target of $210 \mathrm{GW}$ of wind power in 2020 requires an average annual wind power installation of around $9.2 \mathrm{~W}$ per year and per capita during these five years. Comparing the national short-term expansion rate with a target-oriented pathway (around $80 \% \mathrm{CO}_{2}$ emission reduction in 2050 compared to 2010) according to [11], the average expansion rate between 2020 and 2050 has to increase by a factor of four (to around $36 \mathrm{~W}$ per year and per capita). Regarding PV power generation, the regional expansion rate accounts for around $9 \mathrm{~W}$ (Beijing and Tianjin) up to $34 \mathrm{~W}$ (Hebei) per year and per capita average annual installation. For PV, the national target of $105 \mathrm{GW}$ of power in 2020 requires an average annual PV installation of $8.8 \mathrm{~W}$ per year and per capita. Compared to the target-oriented pathway from [11] aiming at $80 \% \mathrm{CO}_{2}$ emission reduction, the average national expansion rate between 2020 and 2050 has to again increase by a factor four (to around $37 \mathrm{~W}$ per year and per capita). This simple comparison demonstrates that investment in infrastructure for renewable energy use have to be significantly increased after 2020 in order to be in line with long-term national energy transition pathways. Regarding additional infrastructure needs related to power storage and transmissions as well as other load-balancing issues, current plans already partly consider integration challenges for long-term development. Increasing pumped hydro storage in Hebei and extending transfer capacity for the supply of Beijing and Tianjin will also be investments supporting the long-term pathway toward higher renewable power shares.

The focus of renewable energy expansion policies should extend from the power sector and increasingly include the heating and transportation sectors. Here it is essential that future policy in the medium term also addresses sector coupling as a means to integrate larger shares of variable renewable energy sources and the corresponding economic benefits (see, e.g., [83]), together with the development of information and communication technologies (ICT) [84]).

As RE heating targets are defined related to the supplied area while the development of living space and residential areas is uncertain today, it remains unclear how far near-term targets and measures are on track with long-term targets. In all energy systems, decarbonization of the heating sector generally poses great challenges and will require strict regulations and huge investments also on the side of efficiency improvement. Regarding primary energy demands, we can also quantitatively compare existing short-term targets and target-oriented long-term scenarios. According to the $80 \%$ $\mathrm{CO}_{2}$ emission reduction scenario of [11], the energy intensity in 2050 will be reduced from around $93 \mathrm{GJ}$ per year and per capita (8.2 MJ/\$GDP PPP) to below 65 GJ per year and per capita (1.4 MJ/\$GDP PPP). This compares to a national efficiency target limit for primary energy consumption at around $105 \mathrm{PJ}$ per year and per capita (7 MJ / \$GDP PPP). This national short-term target corresponds to an annual growth rate of energy intensity of $2.4 \%$ related to population and $-3.1 \%$ related to GDP. Compared to annual growth rates of $-1.6 \%$ related to population and $-5.2 \%$ related to GDP, which are required between 2020 and 2050 in the target-oriented scenario, there is still a significant gap. The regional targets appear to be more ambitious than the national one; however, overall energy demand is strongly influenced 
by local industry structure and population density. Primary energy demand per capita is supposed to increase up to 2020 only between $0.9 \%$ (Shanghai) and $1.8 \%$ (Hebei) per year in the two study regions. In relation to GDP, the negative annual growth rate is between $-5.2 \%$ (Beijing) and $-6.5 \%$ (Tianjin). However, the absolute energy intensity is significantly higher than the national average in most provinces and cities of eastern China. Comparing the intensity targets for 2020, the highest can be found in Tianjin, at 165 PJ per year and per capita. This comparison again demonstrates that the regional targets are quite ambitious but will not lead to an overall reduction of primary energy demand, which appears to be mandatory in order to achieve $\mathrm{CO}_{2}$ reductions in China in line with a global $1.5-2{ }^{\circ} \mathrm{C}$ pathway.

\section{Conclusions}

The analysis provides a reflection of today's energy policy in China and two selected regions with regard to identified challenges and required actions of an energy system transition with the aim of far-reaching decarbonization. Our policy review and analysis reveal that some important and ambitious short-term targets already exist. When further specifying, extending, and integrating target-oriented pathways, policy makers need to consider all relevant infrastructure demands and possibilities to implement new technologies. Several alternative options may exist to achieve decarbonization, and their specific impacts have to be analyzed. This requires more comprehensive and transparent scenario analyses and assessments to significantly broaden the background knowledge for political decision making. A regionally integrated energy system model can provide more sophisticated and robust guidance with uncertainty analysis.

Efficient implementation processes in the future will require taking into account specific local and regional conditions and guaranteeing public acceptance. Specific challenges for the energy system transition in metropolitan regions, such as low RE potential from the hinterland and high pollution burden, call for interregional and inter-sectoral integration. This aspect is addressed by national and regional authorities, especially with regard to power grid extension. However, further analysis will require addressing more available options for sector-coupling and the regional implications. Other examples of ongoing regional integration actions are related to air pollution control and integrated regional transportation systems, but coordination needs to be improved regarding the successful implementation of regional policies.

The analysis shows that long-term $\mathrm{CO}_{2}$ reduction targets require more political action at all administrative levels. There is considerable effort in energy policy in China on the national level, which is committed to achieve peak $\mathrm{CO}_{2}$ emissions by 2030 at the latest. However, energy policy in the analyzed regions is a conglomerate of more or less coordinated actions in line with an overarching national plan. They are focused on near-term targets and lack the long-term perspective necessary for transforming the whole energy system. Long-term vision is necessary to identify the most efficient and feasible transition pathways, to start the development of solutions needed in the long term, and to avoid technical and structural lock-in effects. This not only is important at the national level, but also needs to be identified at the regional policy level, where the implementation of new infrastructures takes place and specific challenges exist. Especially for the eastern coastal regions of China, with their high industrialization and energy density, a convincing and consistent transformation pathway needs to be further explored. The new urban plan of China, addressing continuous urbanization processes and an industrial shift from the eastern coast to central and western regions, could help to transfer successful concepts for regional energy transition to other metropolitan regions and to achieve the successful implementation of national policies. However, it is still worthwhile to examine the key technical and administrative barriers during the implementation of regional policies and targets (e.g., the failure of implementing offshore wind development targets during the 12th Five-year period and the supporting reform in China's power market). 
Author Contributions: M.X. conceived the work, did the policy review and data collection, and wrote the original draft. S.S. and T.P. contributed to the analysis and interpretation of the data and revised the article critically. All three authors did a final approval of the version to be published.

Funding: This research received no external funding.

Conflicts of Interest: The authors declare no conflict of interest.

\section{Abbreviations}

$\begin{array}{ll}\text { BTH } & \text { Beijing-Tianjin-Hebei } \\ \text { CHP } & \text { Combined heat and power (cogeneration) } \\ \text { CE } & \text { Coal equivalent } \\ \text { CREO } & \text { China Renewable Energy Outlook } \\ \text { DH } & \text { District heating } \\ \text { EV } & \text { Electric vehicle } \\ \text { FYP } & \text { Five-Year Plan } \\ \text { gCE } & \text { Gram of coal equivalent } \\ \text { GDP } & \text { Gross domestic product } \\ \text { GHG } & \text { Greenhouse gas } \\ \text { GOJP } & \text { General Office of Jiangsu Province } \\ \text { GOSC } & \text { General Office of the State Council } \\ \text { IEA } & \text { International Energy Agency } \\ \text { IPCC } & \text { Intergovernmental Panel on Climate Change } \\ \text { MHC } & \text { Ministry for Housing and Construction } \\ \text { MIT } & \text { Ministry of Industry and Information Technology } \\ \text { MLR } & \text { Ministry of Land and Resources } \\ \text { NBS } & \text { National Bureau of Statistics } \\ \text { NC } & \text { National Congress } \\ \text { NDRC } & \text { National Development and Reform Commission } \\ \text { NEA } & \text { National Energy Administration } \\ \text { NMLR } & \text { National Ministry of Land and Resources } \\ \text { PPP } & \text { Purchasing power parity } \\ \text { RE } & \text { Renewable energy } \\ \text { RMB } & \text { Renminbi (yuan) } \\ \text { RPS } & \text { Renewable portfolio standard } \\ \text { UN } & \text { United Nations } \\ \text { VRE } & \text { Variable renewable energy } \\ \text { YRD } & \text { Yangtze River Delta } \\ & \end{array}$




\section{Appendix A}

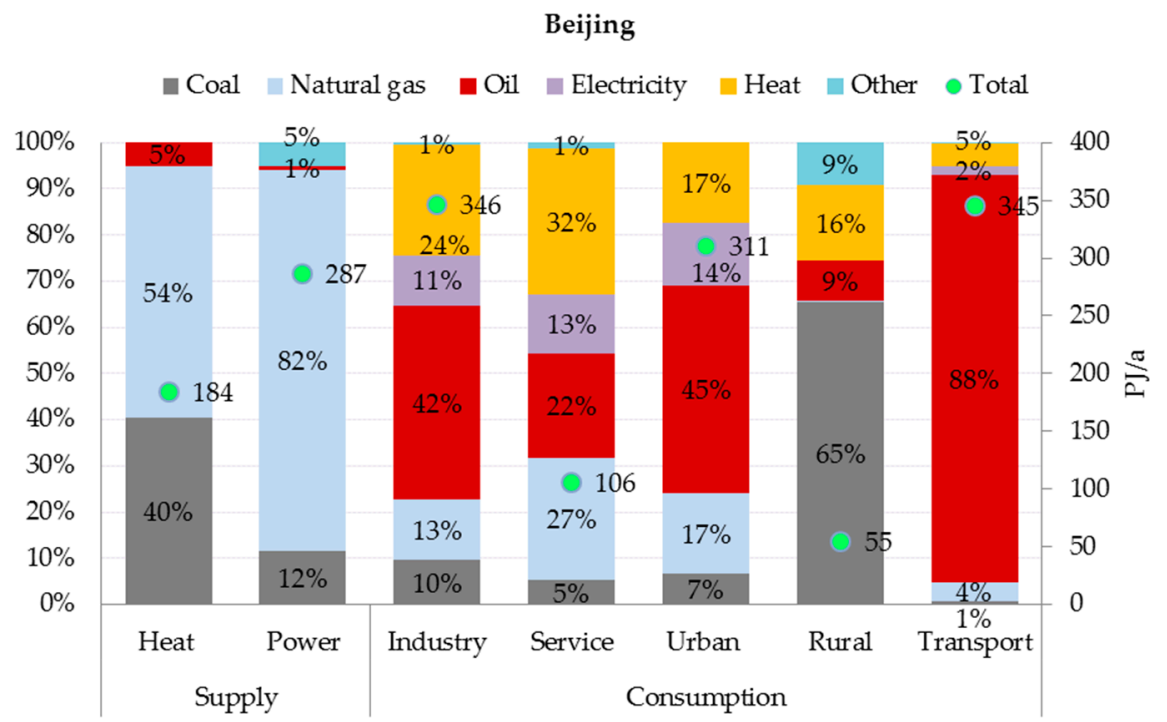

Tianjin

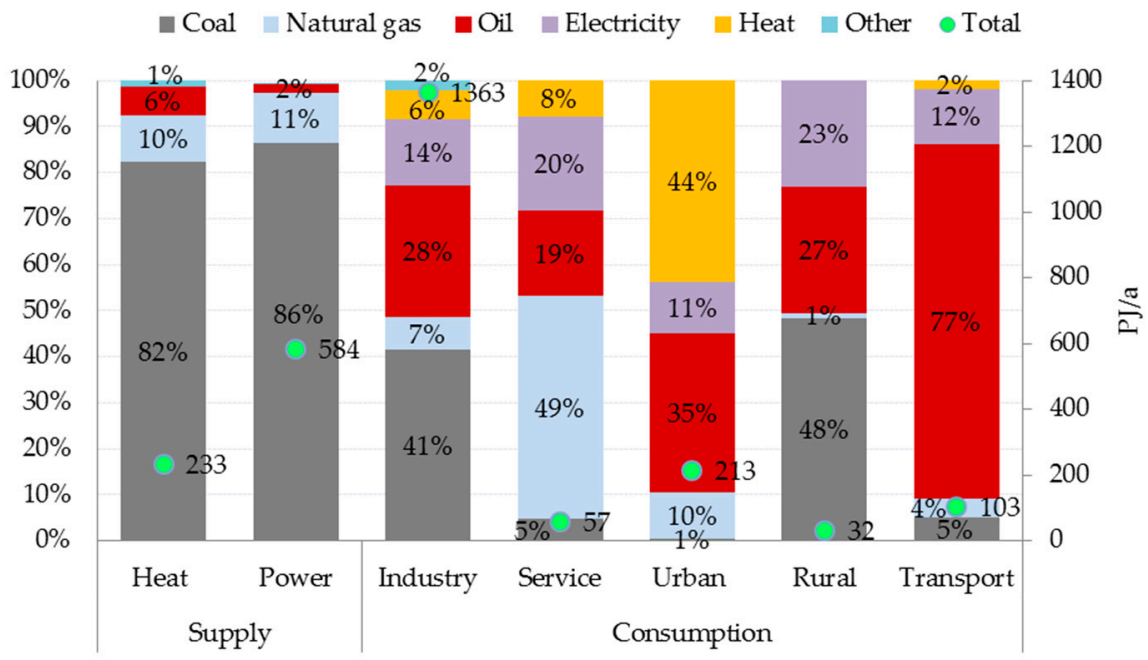

Hebei

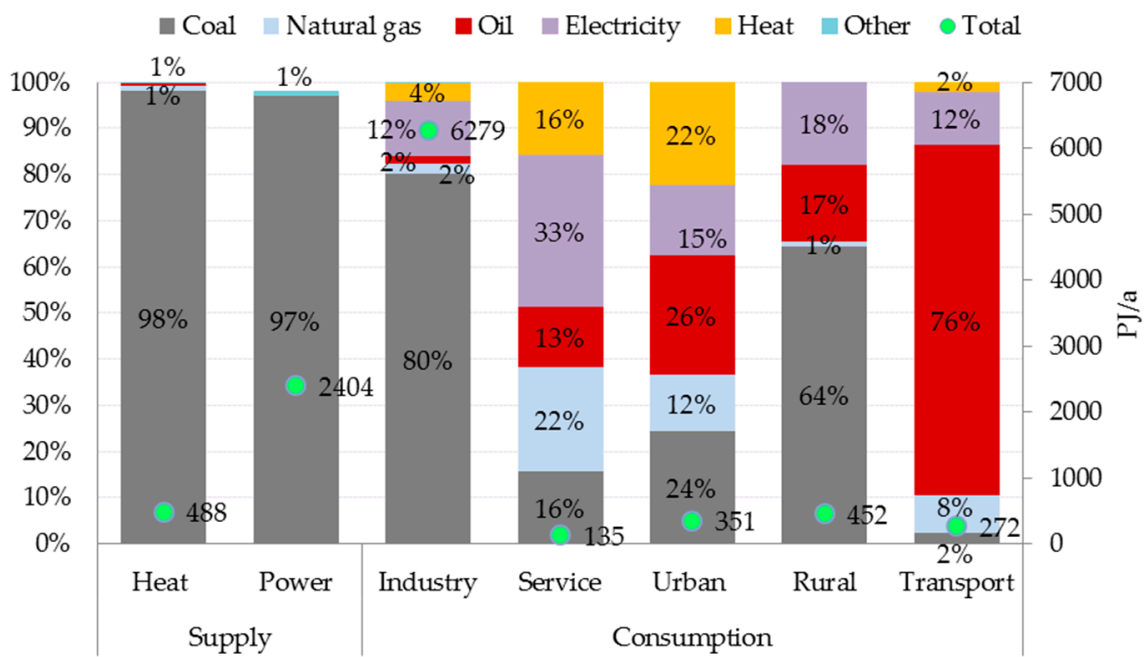

Figure A1. Heat and power energy supply and final energy consumption in BTH region in 2015 by sector [21]. 

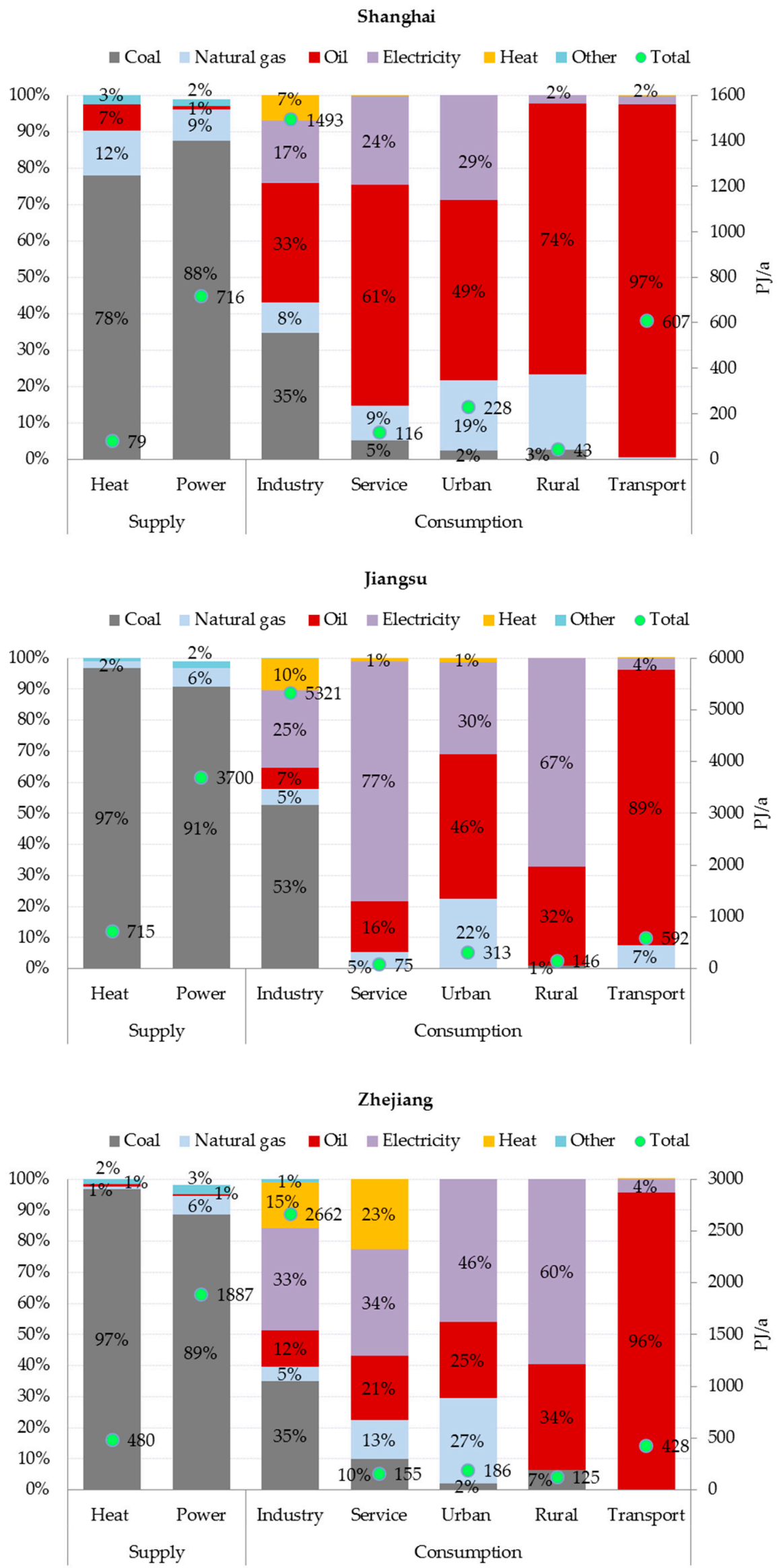

Figure A2. Heat and power energy supply and final energy consumption in YRD region in 2015 by sector [21]. 


\section{China}

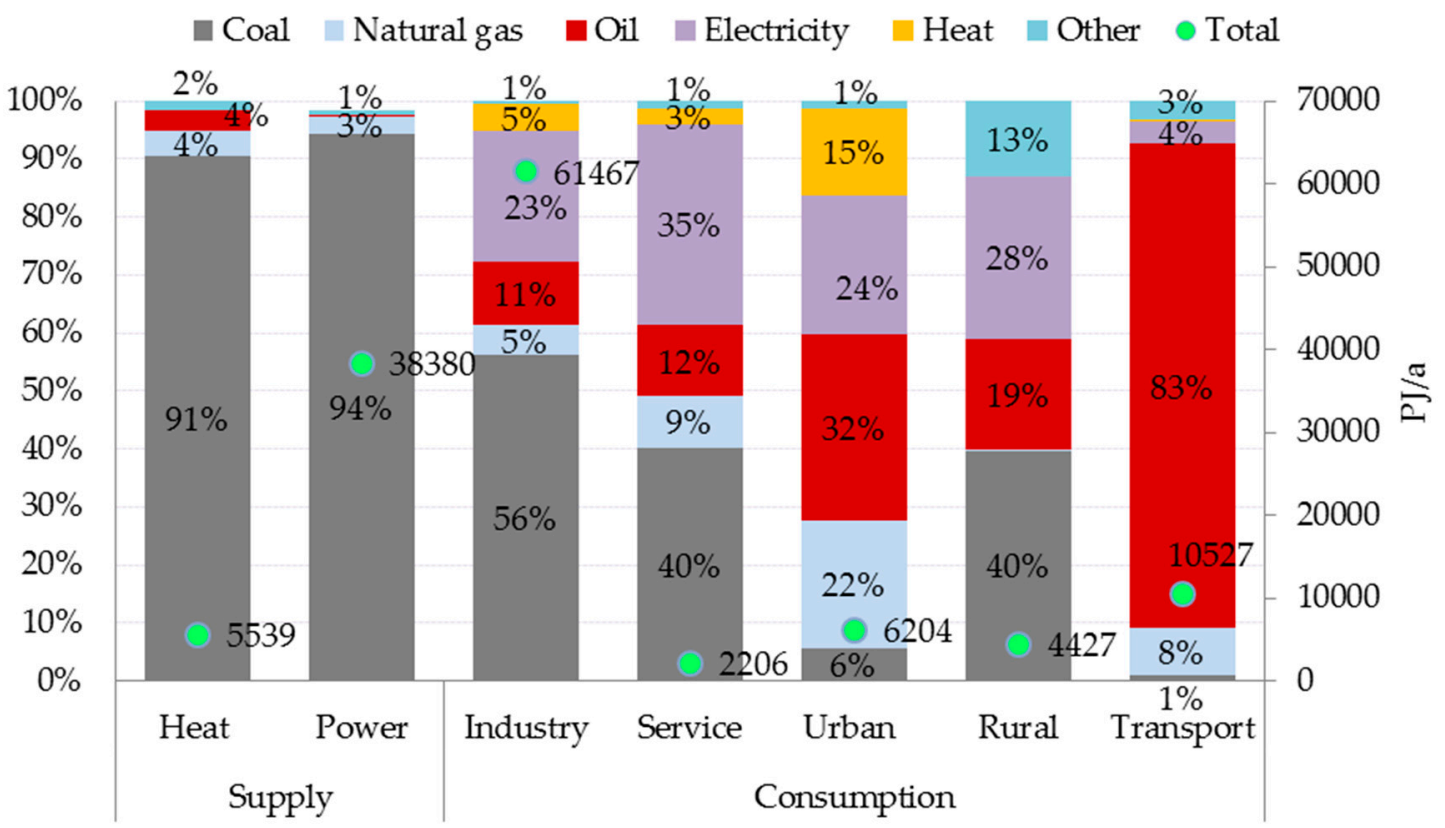

Figure A3. Heat and power energy supply and final energy consumption in China in 2015 by sector [21].

$\mathrm{CO}_{2}$

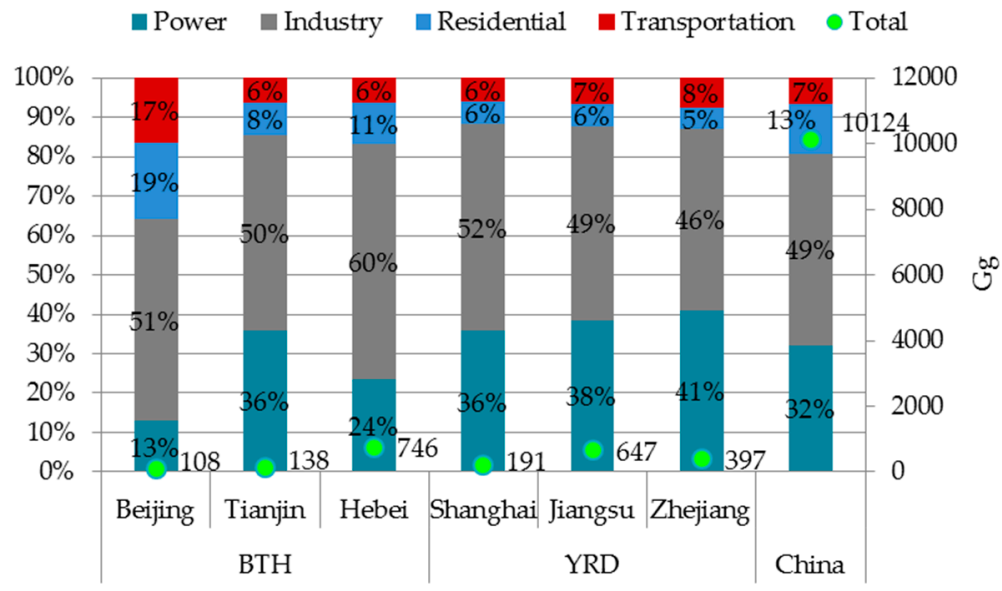

$\mathrm{SO}_{2}$

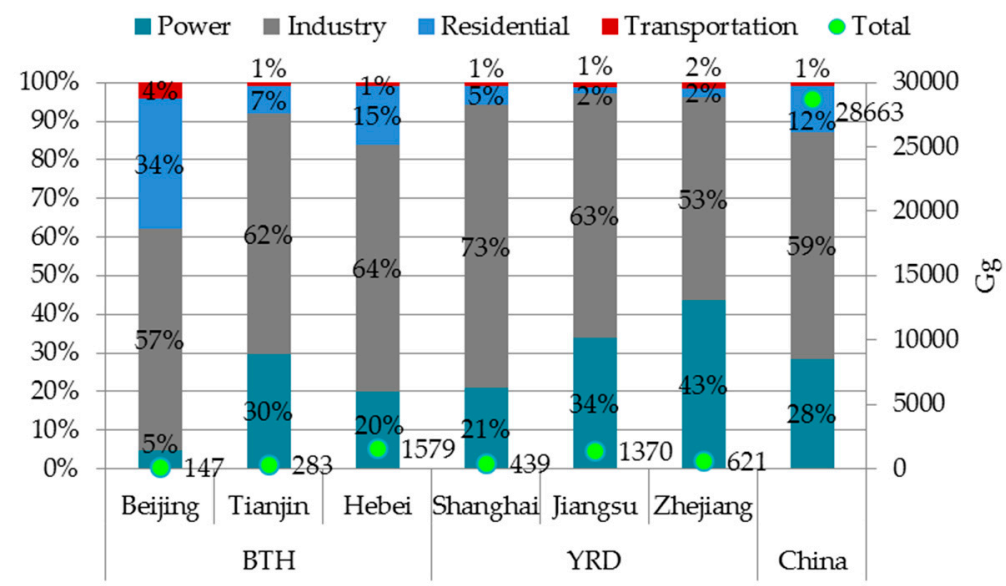

Figure A4. Cont. 

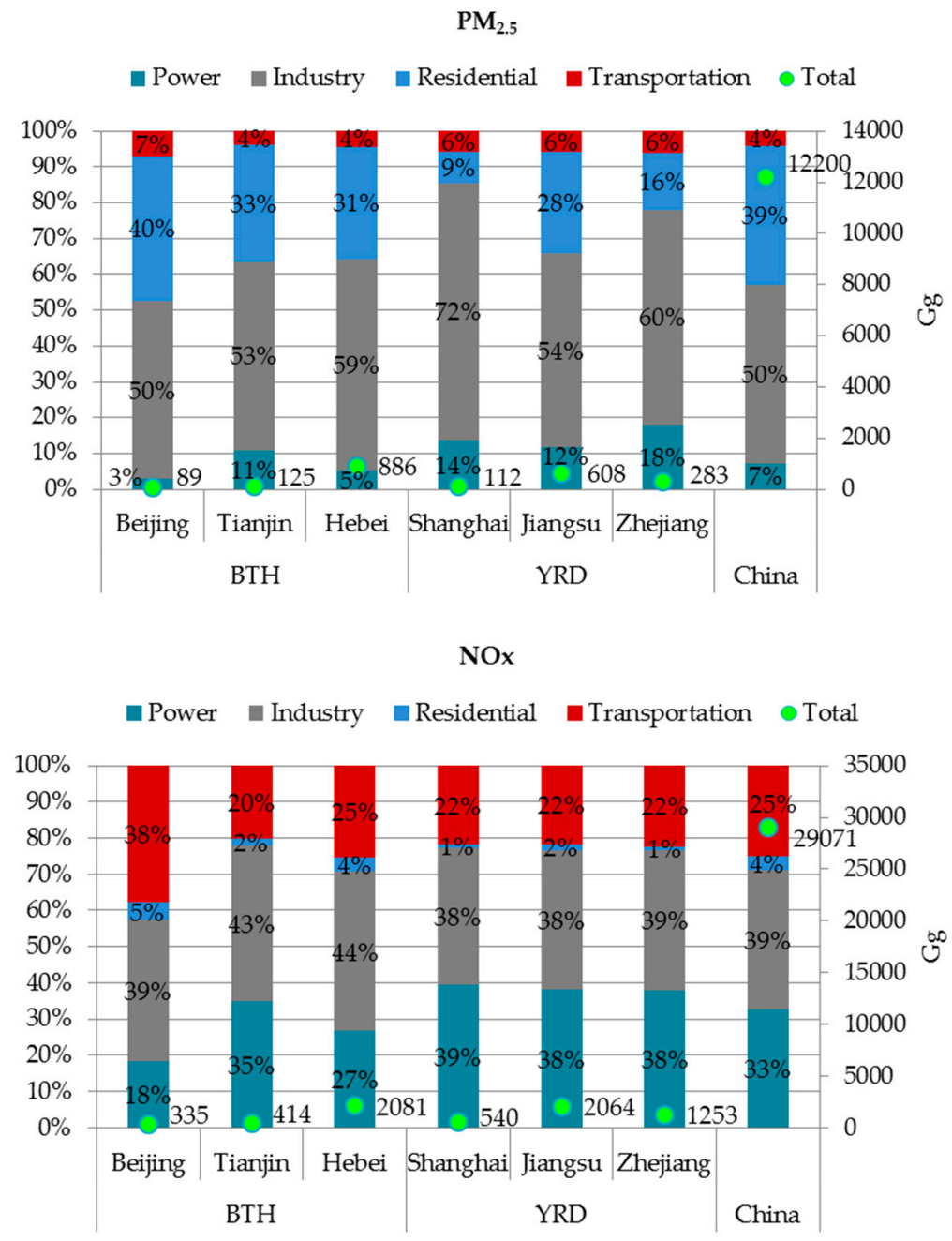

Figure A4. Main emissions of study regions and China in 2010 by sector (data source: Multi-resolution Emission Inventory for China (MEIC) database [84]).

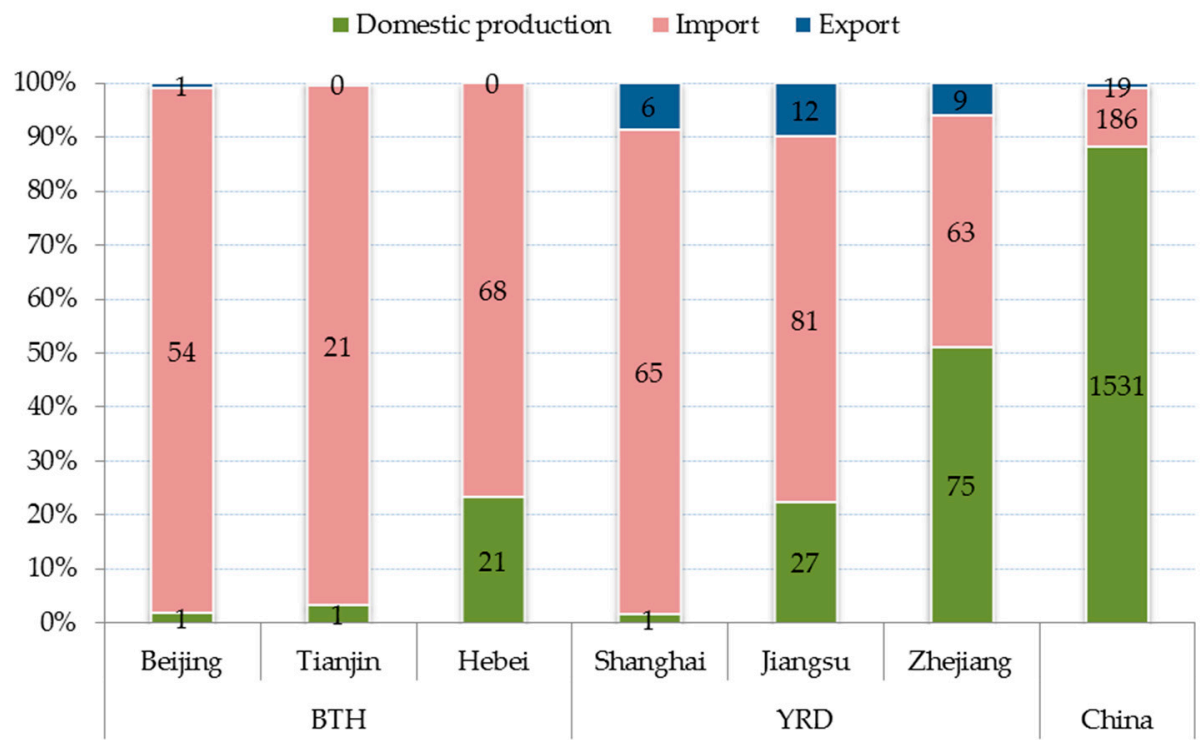

Figure A5. Power exchange (TWh/yr) of study regions and China in 2015 (data source: China Energy Statistical Yearbook 2016 [21]). 


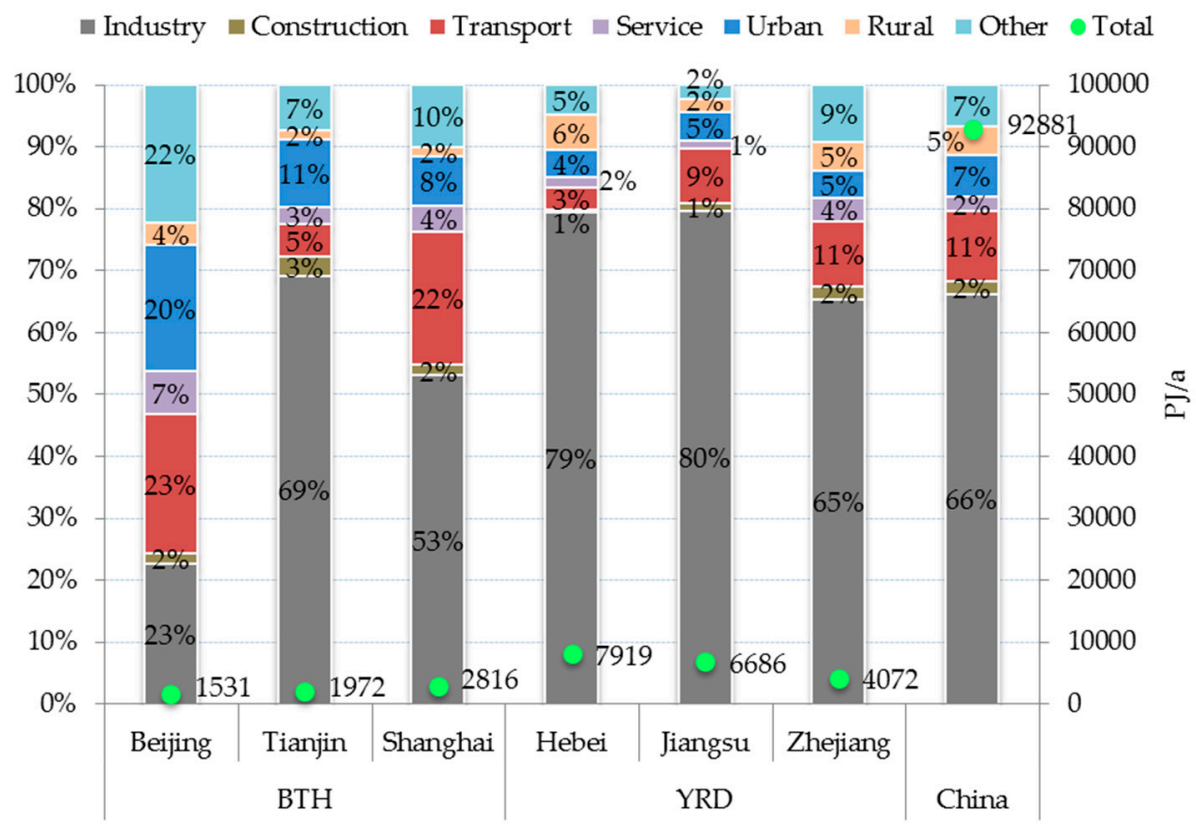

Figure A6. Energy consumption structure of study regions and China in 2015 by sector (data source: China Energy Statistical Yearbook 2016 [21]).

\section{References}

1. IPCC. Exploratory and Normative Scenarios, Intergovernmental Panel on Climate Change; IPCC: Paris, France, 2014.

2. IEA. World Energy Outlook 2017; International Energy Agency: Paris, France, 2017.

3. China Renewable Energy Outlook 2017; China Research Institute of Academy of Macroeconomic Research/NDRC, China National Renewable Energy Center: Beijing, China, 2017.

4. United Nations. The New Urban Agenda; Habitat III: The United Nations Conference on Housing and Sustainable Urban Development; United Nations: New York, NY, USA, 2016.

5. OECD. The Metropolitan Century: Understanding Urbanisation and Its Consequences; OECD: Paris, France, 2015.

6. Lind, A.; Espegren, K. The use of energy system models for analysing the transition to low-carbon cities-The case of Oslo. Energy Strategy Rev. 2017, 15, 44-56. [CrossRef]

7. Simon, S.; Stelzer, V.; Vargas, L.; Paredes, G.; Quintero, A.; Kopfmüller, J. Energy systems. In Risk Habitat Megacity; Springer: New York, NY, USA, 2012; pp. 183-205.

8. China 2050 High Renewable Energy Penetration Scenarion and Roadmap Study; Energy Research Institute of National Development and Reform Commission: Beijing, China, 2015; p. 39.

9. Zhou, Y.; Hao, F.; Meng, W.; Fu, J. Scenario analysis of energy-based low-carbon development in China. J. Environ. Sci. 2014, 26, 1631-1640. [CrossRef] [PubMed]

10. Xunzhang, P.; Wenying, C.; Clarke, L.E.; Lining, W.; Guannan, L. China's energy system transformation towards the $2{ }^{\circ} \mathrm{C}$ goal: Implications of different effort-sharing principles. Energy Policy 2017, 103, 116-126. [CrossRef]

11. Teske, S.; Sawyer, S.; Schäfer, O.; Pregger, T.; Simon, S.; Naegler, T. Energy [R]evolution—A Sustainable World Energy Outlook 2015, 5th ed.; Greenpeace/GWEC: Brussels, Belgium, 2015.

12. NDRC. 13th National Five-Five Plan for Energy Development; National Development and Reform Commission, National Energy Board: Beijing, China, 2017.

13. Bertram, C.; Johnson, N.; Luderer, G.; Riahi, K.; Isaac, M.; Eom, J. Carbon lock-in through capital stock inertia associated with weak near-term climate policies. Technol. Forecast. Soc. Chang. 2015, 90 Pt A, 62-72. [CrossRef]

14. Goldthau, A. Rethinking the governance of energy infrastructure: Scale, decentralization and polycentrism. Energy Res. Soc. Sci. 2014, 1, 134-140. [CrossRef] 
15. Cowell, R.; Ellis, G.; Sherry-Brennan, F.; Strachan, P.A.; Toke, D. Energy transitions, sub-national government and regime flexibility: How has devolution in the United Kingdom affected renewable energy development? Energy Res. Soc. Sci. 2017, 23, 169-181. [CrossRef]

16. Peidong, Z.; Yanli, Y.; Jin, S.; Yonghong, Z.; Lisheng, W.; Xinrong, L. Opportunities and challenges for renewable energy policy in China. Renew. Sustain. Energy Rev. 2009, 13, 439-449. [CrossRef]

17. United Nations, Department of Economic and Social Affairs, Population Division. World Urbanization Prospects; United Nations: New York, NY, USA, 2014.

18. Topi, C.; Esposto, E.; Govigli, V.M. The economics of green transition strategies for cities: Can low carbon, energy efficient development approaches be adapted to demand side urban water efficiency? Environ. Sci. Policy 2016, 58, 74-82. [CrossRef]

19. Freeman, R.; Yearworth, M. Climate change and cities: Problem structuring methods and critical perspectives on low-carbon districts. Energy Res. Soc. Sci. 2017, 25, 48-64. [CrossRef]

20. Wittmayer, J.M.; Loorbach, D. Governing Transitions in Cities: Fostering Alternative Ideas, Practices, and Social Relations Through Transition Management. In Governance of Urban Sustainability Transitions: European and Asian Experiences; Loorbach, D., Wittmayer, J.M., Shiroyama, H., Fujino, J., Mizuguchi, S., Eds.; Springer: Tokyo, Japan, 2016; pp. 13-32, ISBN 978-4-431-55426-4.

21. China Energy Statistical Yearbook; National Bureau of Statistics of the People's Republic of China: Beijing, China, 2016.

22. Meng, M.; Jing, K.; Mander, S. Scenario analysis of CO2 emissions from China's electric power industry. J. Clean. Prod. 2017, 142 Pt 4, 3101-3108. [CrossRef]

23. UNEP. District Energy In Cities: Unlocking the Potential of Energy Efficiency and Renewable Energy; United Nations Environment Programme: Washington, DC, USA, 2015.

24. Li, C.; Shi, H.; Cao, Y.; Wang, J.; Kuang, Y.; Tan, Y.; Wei, J. Comprehensive review of renewable energy curtailment and avoidance: A specific example in China. Renew. Sustain. Energy Rev. 2015, 41, 1067-1079. [CrossRef]

25. Zhao, J.; Wang, J.; Su, Z. Power generation and renewable potential in China. Renew. Sustain. Energy Rev. 2014, 40, 727-740. [CrossRef]

26. Fulton, M.; Cao, J.; Sharples, C.; Capalino, R.; Carboy, M. Scaling Wind and Solar Power in China: Building the Grid to Meet Targets; Deutsche Bank Group, DB Climate Change Advisors: New York, NY, USA, 2012.

27. Kang, C.; Chen, X.; Xu, Q.; Ren, D.; Huang, Y.; Xia, Q.; Wang, W.; Jiang, C.; Liang, J.; Xin, J. Others Balance of power: Toward a more environmentally friendly, efficient, and effective integration of energy systems in China. IEEE Power Energy Mag. 2013, 11, 56-64. [CrossRef]

28. Lenhart, S.; Nelson-Marsh, N.; Wilson, E.J.; Solan, D. Electricity governance and the Western energy imbalance market in the United States: The necessity of interorganizational collaboration. Energy Res. Soc. Sci. 2016, 19, 94-107. [CrossRef]

29. Scholz, Y.; Gils, H.C.; Pietzcker, R. Application of a high-detail energy system model to derive power sector characteristics at high wind and solar shares. Energy Econ. 2017, 64, 568-582. [CrossRef]

30. Gils, H.C.; Scholz, Y.; Pregger, T.; Luca de Tena, D.; Heide, D. Integrated modelling of variable renewable energy-based power supply in Europe. Energy 2017, 123, 173-188. [CrossRef]

31. Michalski, J.; Bünger, U.; Crotogino, F.; Donadei, S.; Schneider, G.-S.; Pregger, T.; Cao, K.-K.; Heide, D. Hydrogen generation by electrolysis and storage in salt caverns: Potentials, economics and systems aspects with regard to the German energy transition. Int. J. Hydrogen Energy 2017, 42, 13427-13443. [CrossRef]

32. Luca de Tena, D.; Pregger, T. Impact of electric vehicles on a future renewable energy-based power system in Europe with a focus on Germany. Int. J. Energy Res. 2018, 42, 2670-2685. [CrossRef]

33. Kempton, W.; Tomić, J. Vehicle-to-grid power implementation: From stabilizing the grid to supporting large-scale renewable energy. J. Power Sources 2005, 144, 280-294. [CrossRef]

34. Regional Policy in China and the EU: A Comparative Perspective; Policies, Information and Services; European Commission: Brussels, Belgium, 2011.

35. Fragkos, P.; Tasios, N.; Paroussos, L.; Capros, P.; Tsani, S. Energy system impacts and policy implications of the European Intended Nationally Determined Contribution and low-carbon pathway to 2050. Energy Policy 2017, 100, 216-226. [CrossRef]

36. Griffiths, S. A review and assessment of energy policy in the Middle East and North Africa region. Energy Policy 2017, 102, 249-269. [CrossRef] 
37. Hall, S.; Foxon, T.J.; Bolton, R. Investing in low-carbon transitions: Energy finance as an adaptive market. Clim. Policy 2017, 17, 280-298. [CrossRef]

38. Huber, M.; Dimkova, D.; Hamacher, T. Integration of wind and solar power in Europe: Assessment of flexibility requirements. Energy 2014, 69, 236-246. [CrossRef]

39. Devine-Wright, P.; Batel, S.; Aas, O.; Sovacool, B.; Labelle, M.C.; Ruud, A. A conceptual framework for understanding the social acceptance of energy infrastructure: Insights from energy storage. Energy Policy 2017, 107, 27-31. [CrossRef]

40. Kammermann, L.; Dermont, C. How beliefs of the political elite and citizens on climate change influence support for Swiss energy transition policy. Energy Res. Soc. Sci. 2018, 43, 48-60. [CrossRef]

41. Dermont, C.; Ingold, K.; Kammermann, L.; Stadelmann-Steffen, I. Bringing the policy making perspective in: A political science approach to social acceptance. Energy Policy 2017, 108, 359-368. [CrossRef]

42. Fraune, C.; Knodt, M. Challenges of Citizen Participation in Infrastructure Policy-Making in Multi-Level Systems-The Case of Onshore Wind Energy Expansion in Germany. Eur. Policy Anal. 2017, 3, 256-273. [CrossRef]

43. Markard, J.; Hoffmann, V.H. Analysis of complementarities: Framework and examples from the energy transition. Technol. Forecast. Soc. Chang. 2016, 111, 63-75. [CrossRef]

44. Muinzer, T.L.; Ellis, G. Subnational governance for the low carbon energy transition: Mapping the UK's 'Energy Constitution'. Environ. Plan. C Polit. Space 2017, 35, 1176-1197. [CrossRef]

45. Stafford, B.A.; Wilson, E.J. Winds of change in energy systems: Policy implementation, technology deployment, and regional transmission organizations. Energy Res. Soc. Sci. 2016, 21, 222-236. [CrossRef]

46. Kuzemko, C.; Lockwood, M.; Mitchell, C.; Hoggett, R. Governing for sustainable energy system change: Politics, contexts and contingency. Energy Res. Soc. Sci. 2016, 12, 96-105. [CrossRef]

47. Spreng, D. Transdisciplinary energy research-Reflecting the context. Energy Res. Soc. Sci. 2014, 1, 65-73. [CrossRef]

48. Schmid, E.; Knopf, B.; Pechan, A. Putting an energy system transformation into practice: The case of the German Energiewende. Energy Res. Soc. Sci. 2016, 11, 263-275. [CrossRef]

49. Rogge, K.S.; Kern, F.; Howlett, M. Conceptual and empirical advances in analysing policy mixes for energy transitions. Energy Res. Soc. Sci. 2017, 33, 1-10. [CrossRef]

50. Shum, K.L. Renewable energy deployment policy: A transition management perspective. Renew. Sustain. Energy Rev. 2017, 73, 1380-1388. [CrossRef]

51. Lutz, L.M.; Fischer, L.-B.; Newig, J.; Lang, D.J. Driving factors for the regional implementation of renewable energy-A multiple case study on the German energy transition. Energy Policy 2017, 105, 136-147. [CrossRef]

52. Luederitz, C.; Abson, D.J.; Audet, R.; Lang, D.J. Many pathways toward sustainability: Not conflict but co-learning between transition narratives. Sustain. Sci. 2017, 12, 393-407. [CrossRef]

53. IEA. Technology Roadmap: Solar Photovoltaic Energy; International Energy Agency: Paris, France, 2014.

54. Wang, C.; Ye, M.; Cai, W.; Chen, J. The value of a clear, long-term climate policy agenda: A case study of China's power sector using a multi-region optimization model. Appl. Energy 2014, 125, 276-288. [CrossRef]

55. GOSC. National Energy Development Strategy and Action Plan (2014-2020); General Office of the State Council: Beijing, China, 2014.

56. Laura, C.; Tim, G.; Paolo, F. Commentary: The Success of Wind and Solar is Powered by Strong Policy Support. 2017. Available online: https://www.iea.org/newsroom/news/2017/june/commentarythesuccess-of-wind-and-solar-is-powered-by-strong-policy-support.html,2017 (accessed on 15 February 2018).

57. Dai, H.; Herran, D.S.; Fujimori, S.; Masui, T. Key factors affecting long-term penetration of global onshore wind energy integrating top-down and bottom-up approaches. Renew. Energy 2016, 85, 19-30. [CrossRef]

58. NDRC. 13th National Five-Year Plan for Power Development; National Development and Reform Commission, National Energy Board: Beijing, China, 2016.

59. NDRC. 13th National Five-Year Plan for Renewable Energy Development; National Development and Reform Commission: Beijing, China, 2016.

60. Xiong, W.; Wang, Y.; Mathiesen, B.V.; Zhang, X. Case study of the constraints and potential contributions regarding wind curtailment in Northeast China. Energy 2016, 110, 55-64. [CrossRef]

61. 13th Five-Year Plan for Power Development in Jiangsu Province; Jiangsu Province Development and Reform Commission: Nanjing, China, 2016. 
62. GOJP Renewable Vehicles Development Actions Plan in Jiangsu Province; General Office of Jiangsu Province: Nanjing, China, 2016.

63. 13th Five Year Plan for Integrated Transportation System Development in Jiangsu Province; General Office of Jiangsu Province: Nanjing, China, 2018.

64. Fagerberg, J.; Laestadius, S.; Martin, B.R. The Triple Challenge for Europe: The Economy, Climate Change and Governance; Centre for Technology, Innovation and Culture, University of Oslo: Oslo, Norway, 2015.

65. Moss, T.; Becker, S.; Naumann, M. Whose energy transition is it, anyway? Organisation and ownership of the Energiewende in villages, cities and regions. Local Environ. 2015, 20, 1547-1563. [CrossRef]

66. Tang, S.; Sui, Y.; Li, J.; Chen, J. Synergy Mechanism Research Based on the Integration of Beijing-Tianjin-Hebei Region. In Proceedings of 2015 2nd International Conference on Industrial Economics System and Industrial Security Engineering; Li, M., Zhang, Q., Zhang, J., Li, Y., Eds.; Springer: Singapore, 2016; pp. 181-185, ISBN 978-981-287-655-3.

67. Li, J.; Lin, B. Does energy and $\mathrm{CO}_{2}$ emissions performance of China benefit from regional integration? Energy Policy 2017, 101, 366-378. [CrossRef]

68. Zhao, G.; Guerrero, J.M.; Jiang, K.; Chen, S. Energy modelling towards low carbon development of Beijing in 2030. Energy 2017, 121, 107-113. [CrossRef]

69. 13th Five-Year Plan for Beijing-Tianjin-Hebei Region Renewable Energy Development; National Development and Reform Commission (NDRC): Beijing, China, 2016.

70. 13th Five-Year Plan for Energy Development in Beijing; Beijing Development and Reform Commission: Beijing, China, 2017.

71. Li, Y.; Wu, F. The emergence of centrally initiated regional plan in China: A case study of Yangtze River Delta Regional Plan. Habitat Int. 2013, 39, 137-147. [CrossRef]

72. Wen, A.; Jing, Y. EU Low-carbon Revolution's Influence on the Yangtze River Delta Regional Development and Its Countermeasures. Energy Procedia 2011, 5, 2289-2302. [CrossRef]

73. GOSC. Action Plan on Prevention and Control of Air Pollution; General Office of the State Council: Beijing, China, 2013.

74. NEA. Renewable Portfolio Standard Policy (RPS); National Energy Administration: Beijing, China, 2016.

75. Lu-Hill, O.; Chen, J. Supporting Measures for Building Efficiency Improvement Projects in Shanghai. Available online: http:/ / www.gbmap.org/article1.php?id=494 (accessed on 1 November 2018).

76. Kevin, M. Financing Energy-Efficient Buildings in Chinese Cities; Paulson Institute: Beijing, China, 2016.

77. On Going Program of Carbon Trading in 5 Municipalities and 2 Provinces. Available online: https://www. china5e.com/subject/show_750.html (accessed on 1 November 2018).

78. Yanfei, W. National Carbon Market Launched for Power Sector 2017. Available online: http://www. chinadaily.com.cn/a/201712/19/WS5a38b293a3108bc8c6735acb.html (accessed on 12 October 2018).

79. Liu, W.X. China Auto Association: 2016 New Energy Vehicle Production and Sales Were over 500,000, an Increase of about 50\%. Available online: https://www.d1ev.com/news/shuju/48462 (accessed on 24 February 2017).

80. Pregger, T.; Nitsch, J.; Naegler, T. Long-term scenarios and strategies for the deployment of renewable energies in Germany. Energy Policy 2013, 59, 350-360. [CrossRef]

81. Pye, S.; Sabio, N.; Strachan, N. An integrated systematic analysis of uncertainties in UK energy transition pathways. Energy Policy 2015, 87, 673-684. [CrossRef]

82. Noel, L. The hidden economic benefits of large-scale renewable energy deployment: Integrating heat, electricity and vehicle systems. Energy Res. Soc. Sci. 2017, 26, 54-59. [CrossRef]

83. Canzler, W.; Engels, F.; Rogge, J.-C.; Simon, D.; Wentland, A. From "living lab" to strategic action field: Bringing together energy, mobility, and Information Technology in Germany. Energy Res. Soc. Sci. 2017, 27, 25-35. [CrossRef]

84. Multi-Resolution Emission Inventory for China v.1.0; MEIC Database. Available online: http://www. meicmodel.org/index.html (accessed on 15 October 2017).

(C) 2019 by the authors. Licensee MDPI, Basel, Switzerland. This article is an open access article distributed under the terms and conditions of the Creative Commons Attribution (CC BY) license (http://creativecommons.org/licenses/by/4.0/). 